\title{
T cell killing by tolerogenic dendritic cells protects mice from allergy
}

\author{
Ulrike Luckey, ${ }^{1}$ Marcus Maurer, ${ }^{2}$ Talkea Schmidt, ${ }^{1}$ Nadine Lorenz,, \\ Beate Seebach, ${ }^{1}$ Martin Metz, ${ }^{2}$ and Kerstin Steinbrink ${ }^{1}$
}

\author{
1Department of Dermatology, University Medical Center, Johannes Gutenberg University Mainz, Mainz, Germany. \\ 2Department of Dermatology and Allergy, Allergie-Centrum-Charité, Charité — Universitätsmedizin Berlin, Berlin, Germany.
}

\begin{abstract}
It is well established that allergy development can be prevented by repeated low-dose exposure to contact allergens. Exactly which immune mechanisms are responsible for this so-called low zone tolerance (LZT) is not clear, although $\mathrm{CD8}^{+}$suppressor $\mathrm{T}$ cells are known to have a role. Here, we show that TNF released by tolerogenic $\mathrm{CD}^{+} \mathrm{CD8}^{+} \mathrm{DCs}$ located in skin-draining lymph nodes is required and sufficient for development of tolerance to contact allergens in mice. DC-derived TNF protected mice from contact allergy by inducing apoptosis in allergen-specific effector $\mathrm{CD8}^{+} \mathrm{T}$ cells via TNF receptor 2 but did not contribute to the generation and function of the regulatory $T$ cells associated with LZT. The TNF-mediated killing mechanism was induced in an allergen-specific manner. Activation of tolerogenic DCs by LZT CD8 ${ }^{+}$suppressor T cells and enhanced TNF receptor 2 expression on contact allergen-specific $\mathrm{CD}^{+}$effector $\mathrm{T}$ cells were required for $\mathrm{LZT}$. Our findings may explain how tolerance protects from allergic diseases, which could allow for the development of new strategies for allergy prevention.
\end{abstract}

\section{Introduction}

Although everyone is exposed to a multitude of potent contact allergens, contact allergies affect only about $10 \%$ of the population (1). It is widely held that tolerance induction by repeated low-dose exposure, i.e., low-zone tolerance (LZT), is the main protective mechanism in those who do not develop allergies (refs. 2-4 and Supplemental Figure 1, A and B; supplemental material available online with this article; doi:10.1172/JCI45963DS1). Conversely, failure to establish LZT, e.g., because of high-dose exposure during the first contact with an allergen, is thought to result in the development of contact allergy. LZT is maintained by $\mathrm{CD}^{+}$suppressor $\mathrm{T}$ cells, which develop in response to IL-10 released by regulatory $\mathrm{CD} 4^{+} \mathrm{T}$ cells during the induction phase of LZT (refs. 5, 6, and Supplemental Figure 1, A and B). However, the precise molecular and cellular pathways of LZT remain unidentified. Consequently, the induction of LZT cannot be used (yet) to prevent contact allergies such as allergic contact dermatitis (ACD), the most common occupational disease in the US and Europe.

TNF is a pleiotropic cytokine that regulates various cellular responses including growth, differentiation, inflammation, immune regulation, and apoptosis (7-10). In addition, TNF exhibits immunosuppressive effects and may be involved in the control of autoimmune diseases $(7,10)$. The effects of TNF are mediated by 2 distinct receptors, TNF receptor 1 (TNFR1 or p55) and TNF receptor 2 (TNFR2 or p75) (7-9). They are coexpressed in most tissues and cell types including $\mathrm{T}$ cells, but through the activation of different signaling cascades, they can mediate distinct cellular immune reactions including apoptosis. Here, we sought to determine the role of TNF in tolerance (LZT) to allergens. We focused on immune responses during the effector phase of $\mathrm{LZT}$, which are critical for the inhibition of allergen-specific, IFN- $\gamma$-producing effector $\mathrm{CD}^{+} \mathrm{T}$ cells of contact hypersensitivity (CHS), the classical mouse model for human ACD $(1,11)$.

Authorship note: Ulrike Luckey and Marcus Maurer contributed equally to this Authors.

Conflict of interest: The authors have declared that no conflict of interest exists. Citation for this article: JClin Invest. 2011;121(10):3860-3871. doi:10.1172/JCI45963.

\section{Results}

$T N F$ and $p 75$ signaling are required for tolerance to contact allergens. Allergen-restimulated lymph node cells from mice subjected to LZT (details for LZT protocol; Supplemental Figure 1, A and B) showed markedly increased production of TNF (Figure 1A), a cytokine known to exert immunosuppressive effects and to be involved in the control of autoimmune diseases via p55 (TNFR1) and p75 (TNFR2) (7-9). Thus, we assessed the relevance of TNF in LZT using TNF-deficient (Tnf/-) mice as well as TNF receptordeficient mice $\left(p 55^{-/}, p 75^{--}, p 55^{-/} p 75^{-/}\right.$; Figure 1, B-E).

Notably, Tnf $)^{-}, p 55^{-/-} p 75^{-/-}$, and $p 75^{-/-}$mice failed to develop LZT as demonstrated by normal, i.e., not inhibited, CHS reactions in vivo, whereas $p 55^{-/}$animals showed normal LZT (Figure 1, B and C). Tnf ${ }^{--}, p 55^{-/} p 75^{-/-}$, and $p 75^{-/-}$mice, but not $p 55^{-/-}$mice, also failed to exhibit reduced IFN- $\gamma$ and IL-2 release and reduced $C D 8^{+}$ $\mathrm{T}$ cell proliferation upon allergen restimulation, 2 hallmark features of LZT (Figure 1, D and E, and refs. 2-6). This indicates that TNF and its receptor p75 are critical for the development of LZT.

TNF and $p 75$ are critical for the effector phase of LZT, but do not contribute to the generation of regulatory $T$ cells during LZT induction. TNF is known to affect $\mathrm{T}$ cell development and proliferation, and it is involved in the modulation of regulatory $T$ cell functions $(7,10,12)$. Thus, we speculated that TNF affects the induction phase of LZT, i.e., the generation of IL-10-producing regulatory $\mathrm{CD} 4^{+} \mathrm{T}$ cells in LZT. However, experiments performed with mice deficient for TNF or TNF receptors revealed normal numbers of IL-10-producing $\mathrm{CD}^{+}$regulatory $\mathrm{T}$ cells after tolerization (Supplemental Figure 2), which excluded TNF as a major inducer of regulatory $\mathrm{CD} 4^{+} \mathrm{T}$ cells in LZT and as a critical signal in the induction of LZT.

We then hypothesized that TNF is essential during the effector phase of LZT. To test this, we adoptively transferred $\mathrm{CD}^{+} \mathrm{T}$ cells obtained from tolerized $T n f /-$ or WT mice to naive WT mice. We found that transfer of $\mathrm{Tnf}^{-1} \mathrm{CD} 8^{+} \mathrm{T}$ cells resulted in robust $\mathrm{LZT}$ responses, as demonstrated by inhibited CHS responses (Figure 2A), reduced hapten-specific $\mathrm{T}$ cell proliferation (Figure 2B), and skewing to a LZT cytokine profile (diminished Tc1 cytokine secretion [IFN- $\gamma$, IL-2]) (Figure 2C). In contrast, the adoptive transfer of 
A

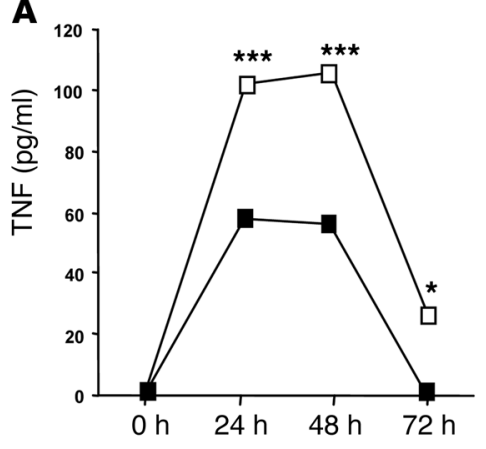

$\square$ Tolerized $(4.5 \mu \mathrm{g} \mathrm{TNCB}) \rightarrow$ CHS

Mock-tolerized (solvent) $\rightarrow$ CHS
B

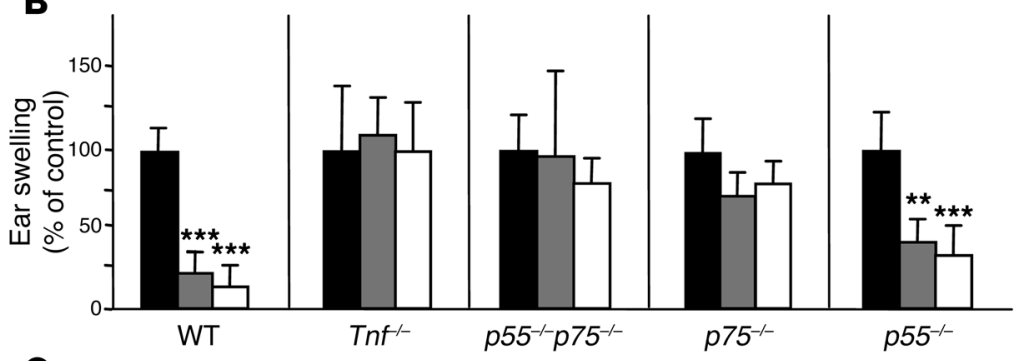

C

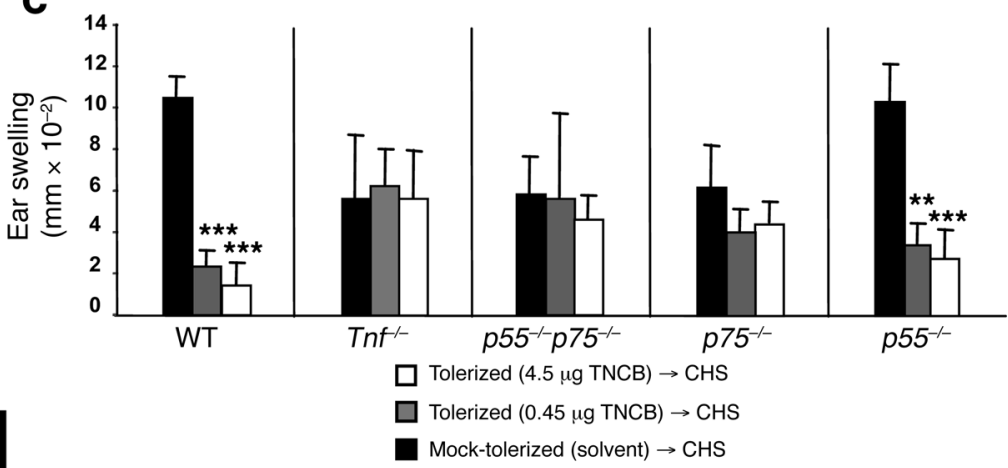

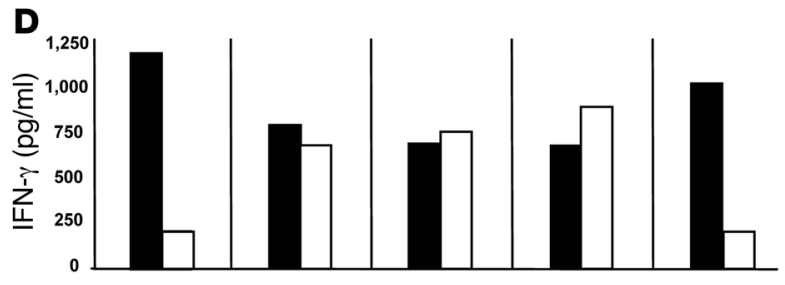

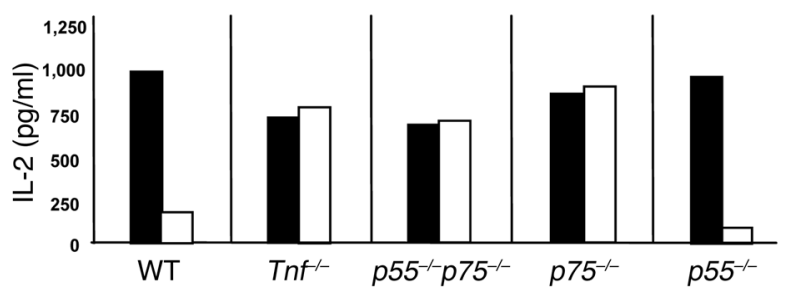

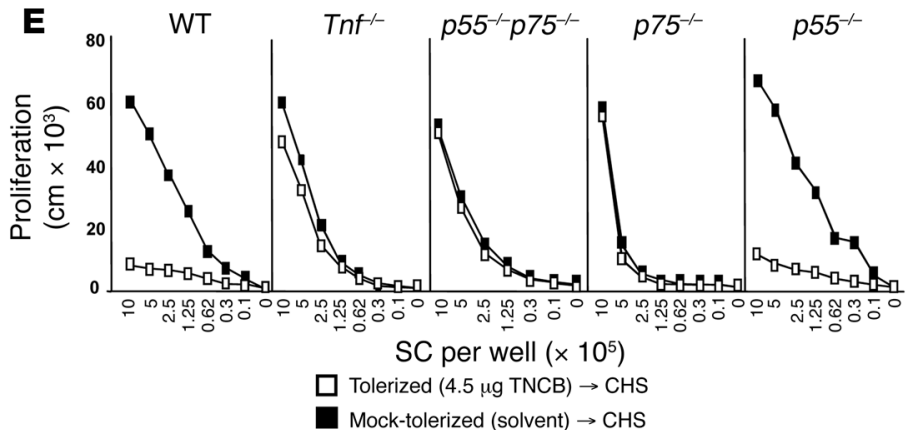

Figure 1

TNF and p75 are required for LZT. (A) Release of TNF 24, 48, and 72 hours after hapten-specific restimulation of lymph node cells obtained from tolerized (TNCB $4.5 \mu \mathrm{g}$ ), sensitized, and challenged mice versus mock-tolerized (solvent), sensitized, and challenged mice ( $n=6$ per group per experiment, data shown are pooled from 5 experiments). (B-E) Efficacy of LZT as quantified by assessing CHS-induced ear swelling and CD8 ${ }^{+} T$ cell cytokine pattern and proliferation after restimulation. Data represent $\mathrm{CHS}$-induced relative (B) and absolute (C) changes in ear thickness, (D) IFN- $\gamma$ and IL-2 production of CD8 ${ }^{+} \mathrm{T}$ cells (detected by ELISA), and (E) T cell proliferation (in $\mathrm{cpm}$, incorporation of $\left[{ }^{3} \mathrm{H}\right]$ thymidine) after haptenspecific restimulation in vitro. B-E show 1 of 3 independent experiments (5-6 mice per group), which all yielded similar results. Data are shown as mean \pm SD. ${ }^{*} P<0.05 ;{ }^{* *} P<0.01 ;{ }^{* *} P<0.001$.

$\mathrm{CD}^{+} \mathrm{T}$ cells from tolerized WT mice to $\mathrm{Tnf}^{/-}$mice did not result in LZT in these recipient mice (Figure 2, D and F). These results indicate that TNF is essential during the effector phase of LZT (inhibition of CHS) but not during the induction of LZT. These results also show that $\mathrm{LZT}$ suppressor $\mathrm{CD}^{+} \mathrm{T}$ cells are not the critical source of TNF themselves, but that they require the presence of TNF to elicit LZT.

In mice, the deficiency for TNF or TNF receptors interferes with the formation of B cell follicles, follicular DC networks, and germinal centers in secondary lymphoid organs $(13,14)$. We therefore performed anti-TNF antibody studies, which showed that neutralization of TNF during the effector phase of LZT but not during the induction phase of LZT significantly inhibited the development of LZT (Supplemental Figure 3, A and B). These findings exclude that abnormalities of lymphatic tissues in TNF or TNF receptor-deficient mice are critical for the inhibition of LZT, thus confirming our data on the importance of TNF obtained in TNF and TNF receptor-deficient mice.

Next, we sought to clarify the role of p75 in LZT. We hypothesized that TNF controls the function of LZT suppressor CD8 ${ }^{+} \mathrm{T}$ cells via $\mathrm{p} 75$. To test this hypothesis, we obtained $\mathrm{CD}^{+} \mathrm{T}$ cells from tolerized $p 75^{-/-}$or WT mice and injected them into WT or $p 75^{-/-}$ animals (Figure 3, A-F). Notably, $p 75^{-1-}$ LZT suppressor $\mathrm{CD}^{+} \mathrm{T}$ cells induced normal LZT in naive WT mice, but WT LZT suppressor $\mathrm{CD}^{+} \mathrm{T}$ cells did not induce LZT in $p 75^{-1-}$ mice (Figure 3, $\mathrm{A}-\mathrm{F})$. This indicates that $\mathrm{p} 75$ is not required for the development of LZT suppressor CD8 ${ }^{+} \mathrm{T}$ cells, whereas it is critical for their LZTpromoting effects during the effector phase of LZT.

p75-expressing CHS effector $C D 8^{+} T$ cells are targets of LZT-promoting TNF. What is the p75-expressing target cell population of TNF during the effector phase of LZT? We hypothesized that this could be the effector T cells of CHS, and we injected tolerized $p 75^{-1-}$ mice with $\mathrm{T}$ cells, 
A
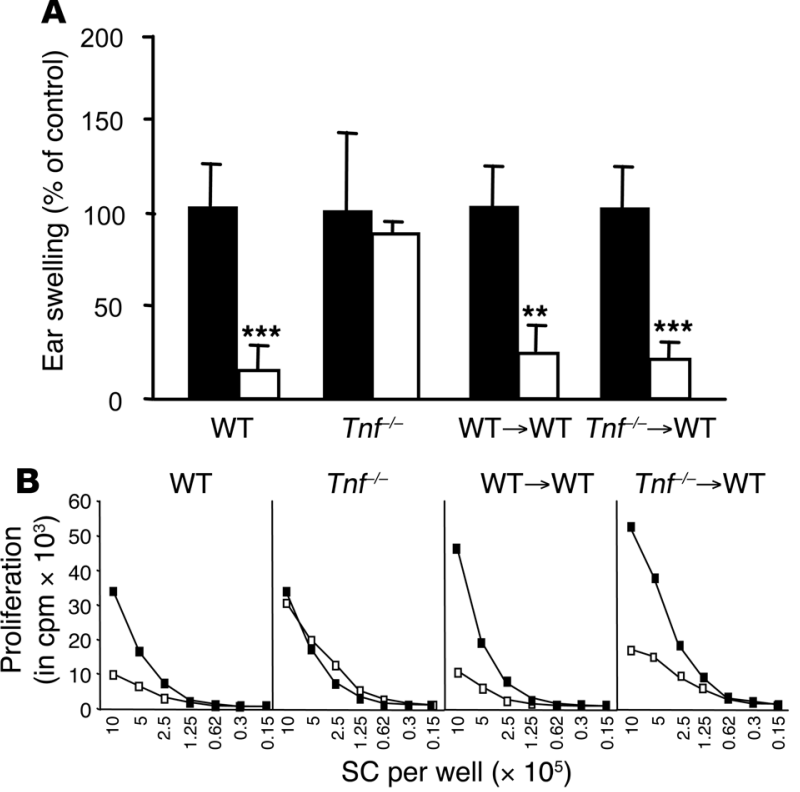

C
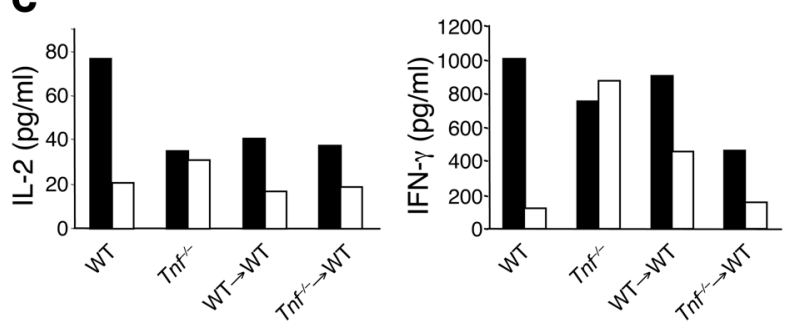
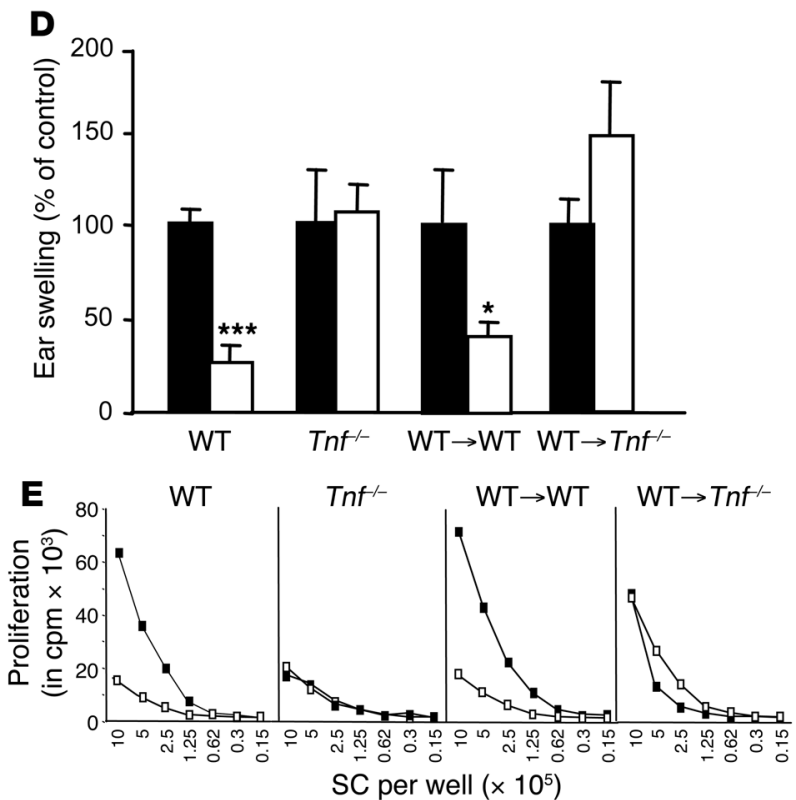

$\mathbf{F}$
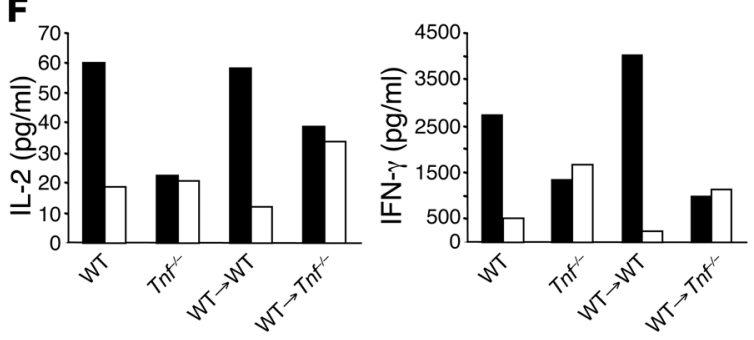

$\square$ Tolerized $(4.5 \mu \mathrm{g}$ TNCB) $\rightarrow$ CHS

Mock-tolerized (solvent) $\rightarrow \mathrm{CHS}$

Figure 2

TNF is critical during the effector phase of LZT. Efficacy of LZT as assessed by measuring inhibition of CHS responses (A and D), T cell proliferation (B and E), and cytokine patterns ( $\mathbf{C}$ and $\mathbf{F}$ ) after restimulation using WT mice, Tnf---, and WT mice injected with lymph node-derived CD8+ T cells from tolerized (white bars and white symbols) or mock-tolerized (solvent-treated; black bars and black symbols) WT mice (WT $\rightarrow$ WT) or from $\mathrm{Tnf}^{-/}$mice $\left(\mathrm{Tnf}^{-1-} \rightarrow \mathrm{WT}\right)$, and $\mathrm{Tnf}^{-/}$mice injected with lymph node-derived CD8 ${ }^{+} \mathrm{T}$ cells from tolerized or mock-tolerized (solvent-treated) WT mice $\left(\mathrm{WT} \rightarrow \mathrm{Tnf}^{--}\right.$) that were subsequently subjected to sensitization and challenge with TNCB (CHS). 1 of 3 independent experiments with similar results is shown (5-6 mice per group and per experiment). Data are shown as mean $\pm \mathrm{SD}$. ${ }^{\star} P<0.05 ;{ }^{* \star} P<0.01 ;{ }^{* \star \star} P<0.001$.

including CHS effector T cells, derived from sensitized WT or $p 75^{-1-}$ animals. We found that LZT was only induced after transfer of WT T cells, but not $p 75^{-1-} \mathrm{T}$ cells, suggesting that CHS effector $\mathrm{T}$ cells need to express p75 for LZT to work (Supplemental Figure 4, A and B). We then performed adoptive transfer experiments with either $\mathrm{CD}^{+}$or $\mathrm{CD}^{+} \mathrm{T}$ cells from sensitized WT mice to specifically assess the importance of $\mathrm{p} 75$ expressed by $\mathrm{CHS}$ effector $\mathrm{CD}^{+} \mathrm{T}$ cells. We found that p75 expression by CHS effector $\mathrm{CD}^{+} \mathrm{T}$ cells is essential and sufficient for LZT, i.e., the prevention of CHS, both in vivo (inhibition of the allergic skin inflammation; Figure 4A) and in vitro (reduction of T cell proliferation and specific cytokine pattern; Figure 4, B and C). Taken together, these results indicate that TNF brings on LZT by acting on p75 expressed by allergen-specific CHS effector CD8 ${ }^{+} \mathrm{T}$ cells.

CHS effector $\mathrm{CD}^{+} \mathrm{T}$ cells exhibit enhanced expression of $\mathrm{p} 75$, which increases their susceptibility to TNF-mediated apoptosis in LZT. Why are CHS effector $\mathrm{CD}^{+} \mathrm{T}$ cells preferential targets of TNF? Flow cytometry analyses revealed that the percentage of $\mathrm{p} 75$-positive $\mathrm{CD}^{+} \mathrm{T}$ cells is significantly increased in hapten-sensitized mice as compared with solvent-treated mice (Figure 5A). To characterize the effect of LZT on $\mathrm{p}^{2} 5^{+} \mathrm{CD} 8 \mathrm{~T}$ cell populations, tolerized (LZT) or solvent-treated (mock-tolerized) Thy $1.1^{+}$mice were reconstituted with $\mathrm{T}$ cells isolated from sensitized Thy $1.2^{+}$mice. This approach allowed us to assess p75 expression in CHS effector $\mathrm{CD}^{+} \mathrm{T}$ cells and in LZT suppressor $\mathrm{CD}^{+} \mathrm{T}$ cells in the same animal. Importantly, in these experiments during the effector phase of tolerance, $\mathrm{p}^{7} 5^{+}$allergen-specific CHS effector $\mathrm{CD}^{+} \mathrm{T}$ cells (Thy $1.2^{+}$), but not recipient $\mathrm{CD}^{+} \mathrm{T}$ cells (Thy $1.1^{+}$), were significantly reduced in LZT mice as compared with mock-tolerized CHS animals (Figure 5B). These results suggest that CHS effector $\mathrm{CD}^{+} \mathrm{T}$ cell numbers are controlled by LZT via p75, possibly by the induction of apoptosis.

LZT is associated with increased TNF/p75-induced apoptosis in CHS effector $C D 8^{+}$T cells. How exactly do TNF and p75 cause LZT? We addressed this question by first asking whether LZT requires the soluble and/or the membrane form of TNF (15-18). Membrane-bound TNF reportedly exhibits a higher avidity to p75 and is superior in activating the p75 receptor as compared with p55 $(8,16)$. We found that memTNF mice, which only express membrane-bound TNF (19), develop normal LZT (reduced ear swelling and typical LZT T cell responses), 

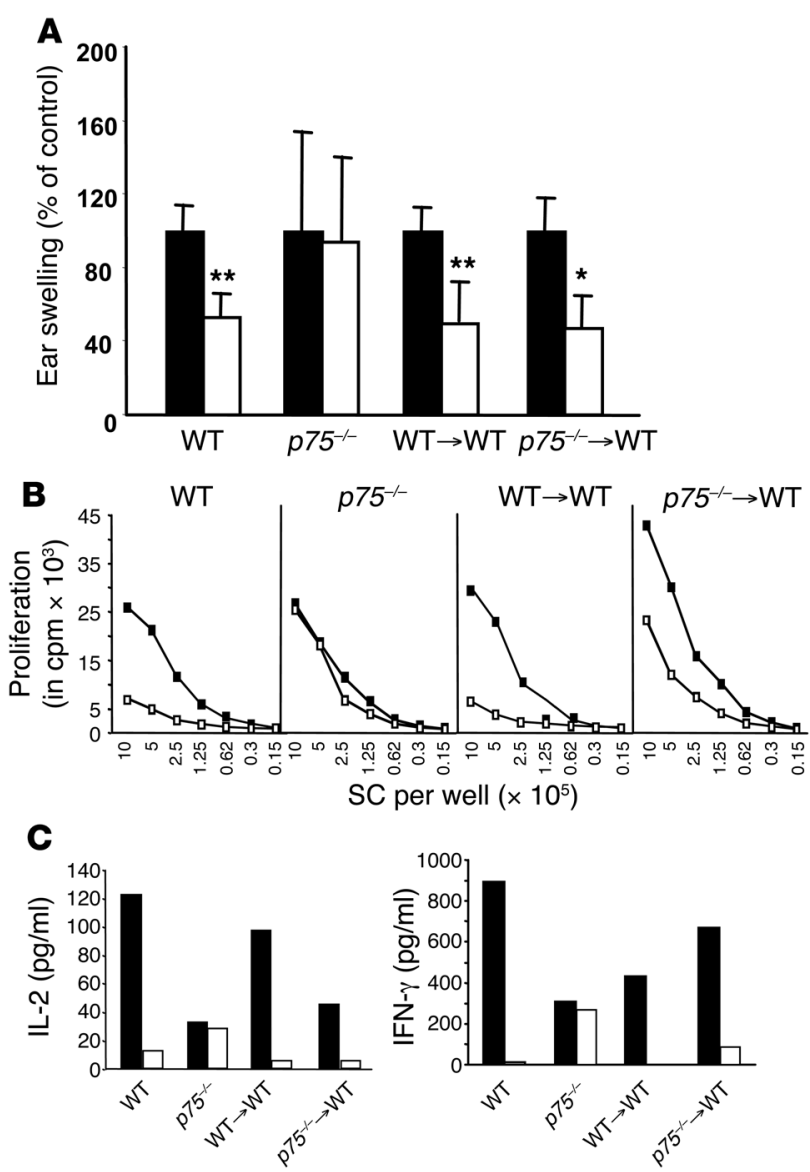

$\square$ Tolerized $(4.5 \mu \mathrm{g}$ TNCB $) \rightarrow$ CHS

Mock-tolerized (solvent) $\rightarrow \mathrm{CHS}$
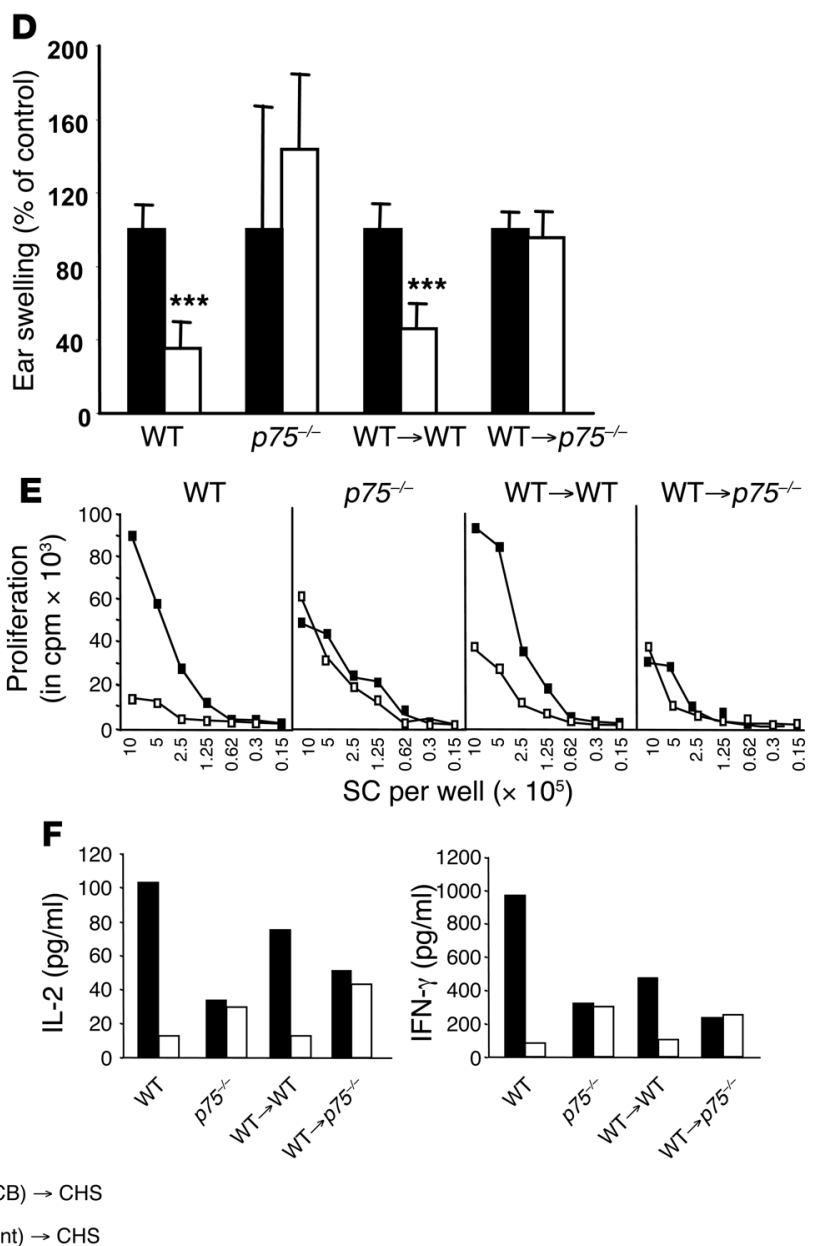

Figure 3

p75-mediated signaling is mandatory during the effector phase of LZT. Efficacy of LZT as assessed by measuring inhibition of CHS responses ( $\mathbf{A}$ and $\mathbf{D})$, T cell proliferation (B and $\mathbf{E}$ ), and cytokine patterns (C and $\mathbf{F})$ after restimulation using tolerized (white bars and white symbols) or mock-tolerized (solvent-treated; black bars and black symbols) WT mice or p75-deficient mice ( $\left.p 75^{-/-}\right)$, WT mice injected with lymph nodederived CD8 $8^{+}$cells from tolerized or solvent-treated WT mice $(\mathrm{WT} \rightarrow \mathrm{WT})$ or from $p 75^{-/-}$mice $\left(p 75^{-/-} \rightarrow\right.$ WT $)$, and $p 75^{-/-}$mice injected with lymph node-derived CD8 ${ }^{+}$T cells from tolerized or solvent-treated WT mice $\left(W T \rightarrow p 75^{--}\right.$) that were subsequently subjected to sensitization and challenge with TNCB to induce CHS. 1 of 3 independent experiments with similar results is shown (5-6 mice per group and per experiment). Data are shown as mean $\pm \mathrm{SD} .{ }^{*} P<0.05 ;{ }^{* *} P<0.01 ;{ }^{* *} P<0.001$.

which indicates that membrane-bound TNF is sufficient for LZT development (Supplemental Figure 5, A and B).

To explore the molecular mechanism(s) that underlie TNF-mediated LZT, we assessed T cells from tolerized mice for various TNFdriven responses including apoptosis $(7,20-22)$. Interestingly, we found that LZT is associated with a marked increase in apoptosis in allergen-specific lymph node $\mathrm{CD}^{+} \mathrm{T}$ cells (Figure 6, A-D). Notably, this increase of apoptotic $\mathrm{CD}^{+} \mathrm{T}$ cells was not observed in tolerized mice deficient for TNF (Figure 6, A and B) or p75 (Figure 6, C and D), which led us to speculate that LZT requires TNF to induce apoptosis in CHS effector $\mathrm{CD}^{+} \mathrm{T}$ cells via $\mathrm{p} 75$.

To formally prove this hypothesis, we again used C57BL/6 mouse strains that express 2 different congenic surface markers (i.e., Thy $1.1^{+}$ mice and Thy $1.2^{+}$mice). We tolerized Thy $1.1^{+}$mice and then injected them with Thy $1.2^{+} \mathrm{CD}^{+} \mathrm{T}$ cells obtained from sensitized animals. This approach allowed us to assess LZT suppressor $\mathrm{CD}^{+} \mathrm{T}$ cells $\left(\right.$ Thy $1.1^{+}$) and CHS effector $\mathrm{CD}^{+} \mathrm{T}$ cells $\left(\right.$ Thy $\left.1.2^{+}\right)$at the same time in the same animal. As shown in Figure 6E, LZT resulted in the pronounced apoptosis of Thy $1.2^{+} \mathrm{CD} 8^{+} \mathrm{T}$ cells, i.e., CHS effector $\mathrm{T}$ cells. Mock-tolerized (solvent-treated) CHS mice did not show increased apoptosis of Thy $1.2^{+} \mathrm{CHS}$ effector $\mathrm{CD}^{+} \mathrm{T}$ cells. These findings show that LZT specifically increases apoptosis in CHS effector T cells.

In order to test the hapten specificity of $\mathrm{T}$ cell apoptosis in LZT, we tolerized Thy $1.1^{+}$mice with 1 hapten, i.e., TNCB, and then injected them with Thy $1.2^{+} \mathrm{CD}^{+} \mathrm{T}$ cells obtained from animals sensitized with a second, unrelated hapten (DNFB) (Figure 6F). In this experiment, we did not observe an increased rate of apoptotic CHS effector $\mathrm{CD}^{+} \mathrm{T}$ cells, and we did not see an inhibition of allergic responses, which demonstrates that LZT is hapten-specific and that apoptosis of CHS effector $\mathrm{CD}^{+} \mathrm{T}$ cells is induced in an antigen-specific manner (Figure 6F).

$T N F$ produced by $C D 8^{+} C D 11 c^{+}$killer DCs is critical for LZT. Finally, we sought to identify the cellular source of LZT-promoting TNF. In former experiments, we found that $\mathrm{B}$ cells and macrophages are 

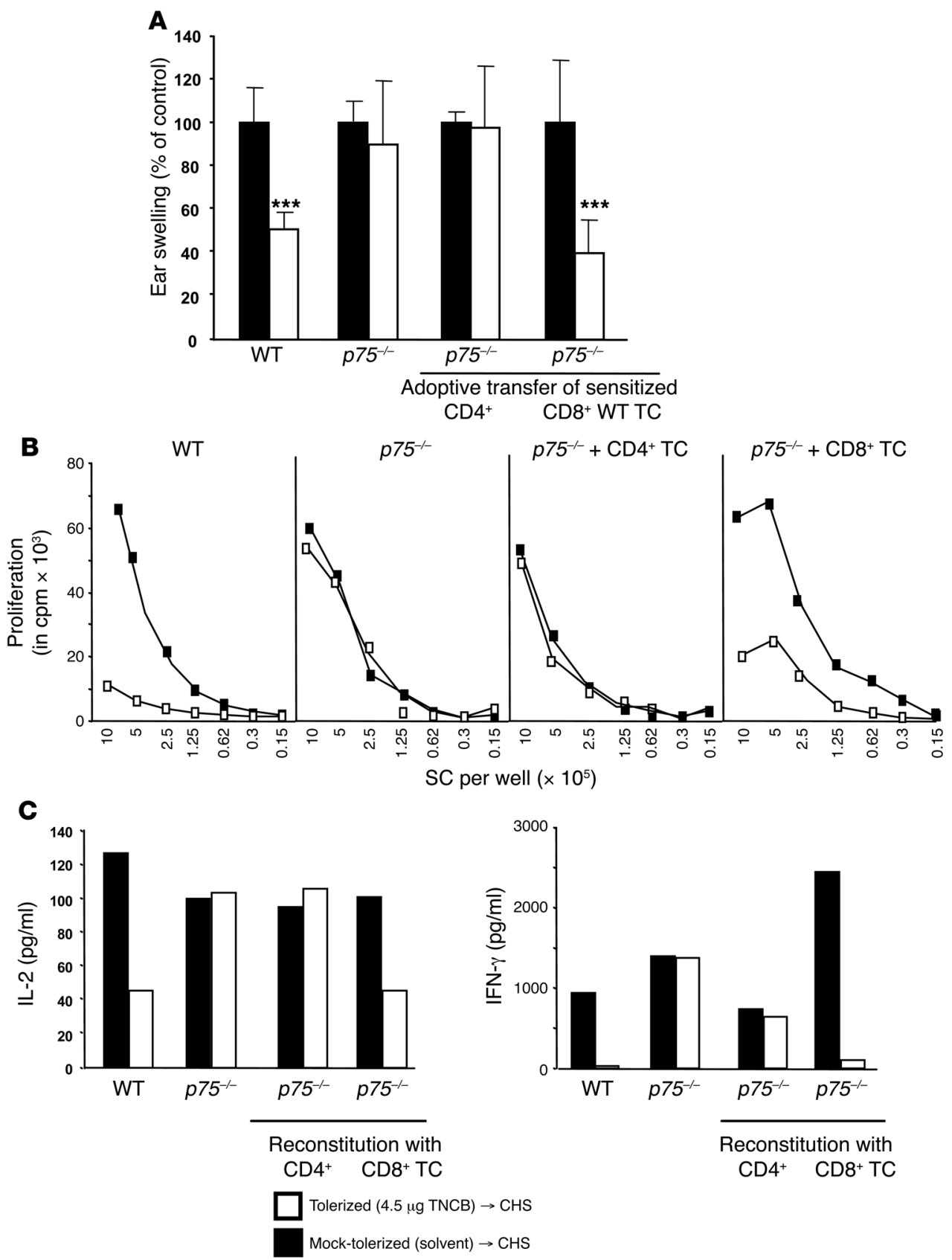

\section{Figure 4}

p75-expressing CD8+ effector T cells of $\mathrm{CHS}$ are targets of TNF during LZT. LZT responses measured by assessing $\mathrm{CHS}$ responses (A), T cell proliferation (B), and cytokine release following restimulation (C) after challenge in tolerized (white bars) or mock-tolerized (solvent-treated; black bars) WT mice and $p 75^{-/-}$mice that were then sensitized and challenged, and in tolerized or solvent-treated p75 $5^{-/-}$mice transferred with CD4+ or $\mathrm{CD}^{+} \mathrm{T}$ cells obtained from sensitized WT mice and subsequently challenged. 1 of 3 independent experiments with similar results is shown (5-6 mice per group and per experiment). Data are shown as mean $\pm \mathrm{SD}$. ${ }^{* \star *} P<0.001$. not required for LZT (ref. 4 and unpublished observations). CHS responses can reportedly also be mediated by NK cells, as demonstrated in various $\mathrm{T}$ and $\mathrm{B}$ cell-deficient transgenic mouse strains $(23,24)$. To test whether NK cells are relevant for LZT, which is traditionally held to be T cell-dependent $(2,5)$, we assessed LZT responses in NK-depleted WT mice. In the absence of NK cells, WT animals developed normal LZT, but exhibited impaired CHS responses, as previously described, thus excluding a critical role for NK cells in LZT (Supplemental Figure 6, A and B, and ref. 23).

Next, we excluded $\mathrm{CD}^{+}$cells as a major source of TNF in LZT by showing that the adoptive transfer of $\mathrm{CD}^{+} \mathrm{TNF}^{+}$cells, but not $\mathrm{CD}^{+} \mathrm{TNF}^{+}$cells, and subsequent tolerization results in $\mathrm{LZT}$ in Tnf ${ }^{\prime-}$ animals (Figure 7A). TNF is produced by many different $\mathrm{CD}^{+}$cell types $(7,25)$. Therefore, we performed intracellular cytokine staining of $\mathrm{CD}^{+} \mathrm{T}$ cells and $\mathrm{CD} 8^{+} \mathrm{CD} 11 \mathrm{c}^{+} \mathrm{DCs}$ derived from tolerized or control mice. These analyses revealed that both lymph node-derived $\mathrm{CD}^{+} \mathrm{T}$ cells and $\mathrm{CD}^{+} \mathrm{DCs}$ express TNF ex vivo and after in vitro restimulation with the relevant hapten (Figure 7B). Notably, the percentage of $\mathrm{TNF}^{+} \mathrm{CD}^{+} \mathrm{CD} 11 \mathrm{c}^{+} \mathrm{DCs}$ was higher than that of $\mathrm{TNF}^{+} \mathrm{CD}^{+} \mathrm{T}$ cells (Figure $7 \mathrm{~B}$ ), suggesting that $\mathrm{CD}^{+} \mathrm{CD} 11 \mathrm{c}^{+} \mathrm{DCs}$ are the relevant source of TNF in LZT. The percentage of $\mathrm{TNF}^{+} \mathrm{CD}^{+} \mathrm{CD} 11 \mathrm{c}^{+} \mathrm{DCs}$ was enhanced during the effector phase of LZT but not in mock-tolerized (solvent-treated) mice (Figure 7C), excluding a constitutive expression of TNF and demonstrating a hapten-specific induction of TNF production.

To directly compare the relevance of $\mathrm{TNF}^{+} \mathrm{CD}^{+} \mathrm{T}$ cells and $\mathrm{TNF}^{+}$ DCs $\left(\mathrm{CD}^{+} \mathrm{CD} 11 \mathrm{c}^{+}\right)$, we tolerized $\mathrm{Tnf}^{/-}$mice and then adoptively transferred them with highly purified (>99.9\%) and viable (85\%-95\%) 
A

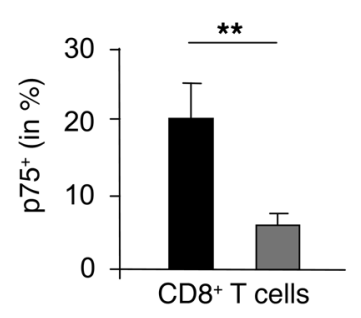

- Sensitized (TNCB)

Mock-sensitized (solvent)
B

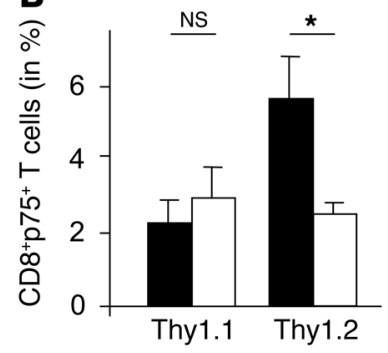

$\square$ Tolerized (4.5 $\mu \mathrm{g}$ TNCB) $\rightarrow \mathrm{CHS}$

$\square$ Mock-tolerized (solvent) $\rightarrow \mathrm{CHS}$
Thy $1.1^{+}$

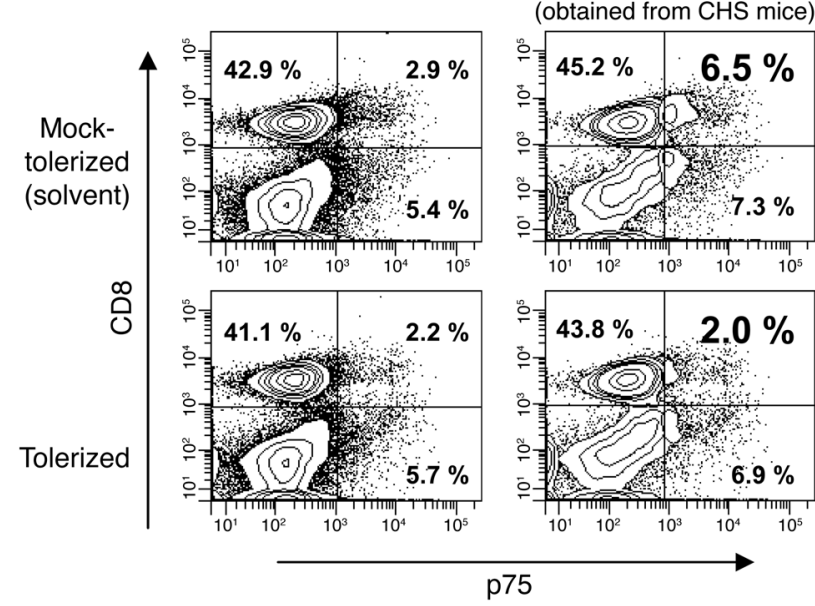

Figure 5

CHS effector CD8 ${ }^{+}$T cells exhibit enhanced expression of p75, which increases their susceptibility to TNF-mediated apoptosis in LZT. (A) Percentage of $\mathrm{p} 75^{+} \mathrm{CD} 8^{+} \mathrm{T}$ cells in sensitized (black bar) and solvent-treated (gray bar) mice as assessed by flow cytometry (pooled data of 6 independent experiments). (B) Percentage of $\mathrm{p} 75^{+} \mathrm{CD} 8{ }^{+} \mathrm{T}$ cells in tolerized (white bars) and mock-tolerized (solvent-treated; black bars) Thy $1.1^{+}$recipient mice (5 per group) that were adoptively transferred with T cells isolated from sensitized Thy $1.2^{+}$mice and then challenged to induce CHS. Gates were set on recipients' Thy $1.1^{+}$cells or Thy $1.2^{+} \mathrm{T}$ cells (derived from the sensitized donor mice). Pooled data from 4 independent experiments (left panel) and data from 1 representative experiment (right panel) are shown. Data are shown as mean $\pm \mathrm{SD}$. ${ }^{*} P<0.05 ;{ }^{* \star} P<0.01$.

$\mathrm{CD}^{+} \mathrm{T}$ cells or $\mathrm{CD} 8^{+} \mathrm{CD} 11 \mathrm{c}^{+}\left(\mathrm{NK} 1.1^{-}, \mathrm{TCR} \alpha \beta^{-}\right)$DCs obtained from skin-draining lymph nodes of naive WT animals (phenotype of $\mathrm{CD}^{+} \mathrm{CD} 11 \mathrm{c}^{+}$in Supplemental Figure 7A). As shown in Figure 8, A and $\mathrm{B}$, the i.v. transfer of $\mathrm{CD}^{+} \mathrm{DCs}$, but not of $\mathrm{CD} 8^{+} \mathrm{T}$ cells, resulted in normal LZT responses in these mice (significantly reduced skin inflammation and prevention of CHS typical Tc1 T cell activation). Notably, reconstitution of $\mathrm{Tnf}^{/-}$mice with $\mathrm{CD} 8^{+} \mathrm{DCs}$ obtained from $\mathrm{Tnf}^{-}{ }^{-}$or with CD8-CD $11 \mathrm{c}^{+}$WT DCs failed to induce LZT (Figure $8, \mathrm{C}-\mathrm{F}$ ), proving that $\mathrm{CD}^{+} \mathrm{CD} 11 \mathrm{c}^{+}$DCs located in skin-draining lymph nodes are the critical source of TNF in LZT.

This conclusion is supported by 5 independent lines of circumstantial evidence: (a) studies of the migration capacity of $\mathrm{CD}^{+} \mathrm{CD} 11 \mathrm{c}^{+} \mathrm{DCs}$ used for reconstitution experiments showed that these cells preferentially migrate to skin-draining lymph nodes during LZT (Supplemental Figure 7B); (b) the injection of CD $8{ }^{+} \mathrm{CD} 11 \mathrm{c}^{+}$ DCs obtained from memTNF mice, which lack the soluble form of TNF, adoptively transferred normal LZT, suggesting that tight DC$\mathrm{T}$ cell interactions in lymph node-related $\mathrm{T}$ cell areas are involved in DC-induced apoptosis of CHS CD8 ${ }^{+}$effector T cells (Figure 8, G and $\mathrm{H})$; (c) analyses of the phenotype of TNF-producing CD8 ${ }^{+} \mathrm{CD} 11 \mathrm{c}^{+}$ DCs revealed a significantly impaired expression of costimulatory molecules including CD80 and GITR ligand (data not shown) - features typical for tolerogenic DCs; (d) LZT suppressor CD8 ${ }^{+} \mathrm{T}$ cells induced TNF expression in $\mathrm{CD}^{+} \mathrm{CD} 11 \mathrm{c}^{+}$killer DCs (Supplemental Figure 8); and (e) finally, in vitro coculture experiments using $\mathrm{CD}^{+} \mathrm{CD} 11 \mathrm{c}^{+} \mathrm{DCs}$ and $\mathrm{CD} 8^{+} \mathrm{T}$ cells showed that DCs obtained from LZT mice induce a significantly higher percentage of apoptosis in $\mathrm{CD}^{+} \mathrm{CHS}$ effector T cells as compared with control DCs (Figure 9). Taken together, these findings support a critical role for killer $\mathrm{CD}^{+} \mathrm{CD} 11 \mathrm{c}^{+}$DCs during the effector phase of LZT.

\section{Discussion}

Here, we demonstrate that TNF is essential for LZT to contact allergens. $\mathrm{CD}^{+} \mathrm{CD} 11 \mathrm{c}^{+}$killer DCs, activated by $\mathrm{LZT}$ suppressor $\mathrm{CD} 8^{+} \mathrm{T}$ cells, induce TNF-driven apoptosis in hapten-specific CHS effector $\mathrm{CD}^{+} \mathrm{T}$ cells via $\mathrm{p} 75$, thereby preventing the development of allergic skin inflammation. The specificity of the target, CHS effector $\mathrm{CD}^{+}$ T cells, can be explained by their high levels of p75 expression and, therefore, increased susceptibility to TNF-mediated apoptosis.

Both TNF receptors (p55 and p75) bind intracellular adaptor proteins that link receptor stimulation to the activation of many signaling processes and cellular responses including apoptosis $(18,20,26)$. Unlike p55, p75 lacks a cytoplasmic death domain. However, it has been reported that p75 also plays an important role in the regulation of apoptosis-mediated cell death $(22,27-32)$, which is in line with the results obtained in our study demonstrating that TNF-induced apoptosis of CHS effector $\mathrm{CD}^{+} \mathrm{T}$ cells via p75 signaling is critical for LZT to allergens. Thus, our findings confirm and extend earlier reports on p75 and its role in $\mathrm{CD}^{+} \mathrm{T}$ cell apoptosis $(20,22,33)$.

TNF is not only known to induce apoptosis in T cells but can also modulate $\mathrm{T}$ cell development and proliferation $(18,34,35)$. Our studies fail to show that TNF is critical for the development and function of $\mathrm{CD}^{+}$suppressor T cells in LZT. A similar observation was made by Erickson and coworkers, who reported a decreased sensitivity to TNF, but normal T cell development, in p75-deficient mice (36). Our results also do not reveal altered functions of $\mathrm{CD}^{+}$regulatory IL-10-producing T cells in the absence of p75-mediated signaling during LZT, which is in line with earlier work showing normal suppressive effects on $\mathrm{T}$ cell proliferation of regulatory $\mathrm{CD} 4^{+} \mathrm{CD} 25^{+} \mathrm{T}$ cells from $\mathrm{p} 75$-deficient mice (37). In contrast, other studies demonstrate that TNF induces a reduction or, in long term culture, an enhancement of number and function of naturally occurring $\mathrm{CD} 4{ }^{+} \mathrm{CD} 25^{+}$regulatory $\mathrm{T}$ cells $(12,38-42)$.

TNF is known to play an important proinflammatory and immuno-activating role in ACD and its murine counterpart CHS $(1,43)$. TNF-, p75-, and p55-deficient mice all show reduced CHS responses due to impaired $\mathrm{APC}$ activation and migration during 
A

WT

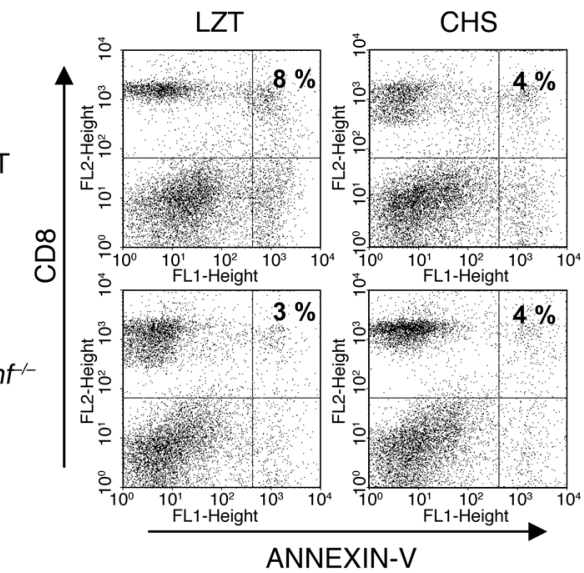

C

WT

$p 75^{--}$
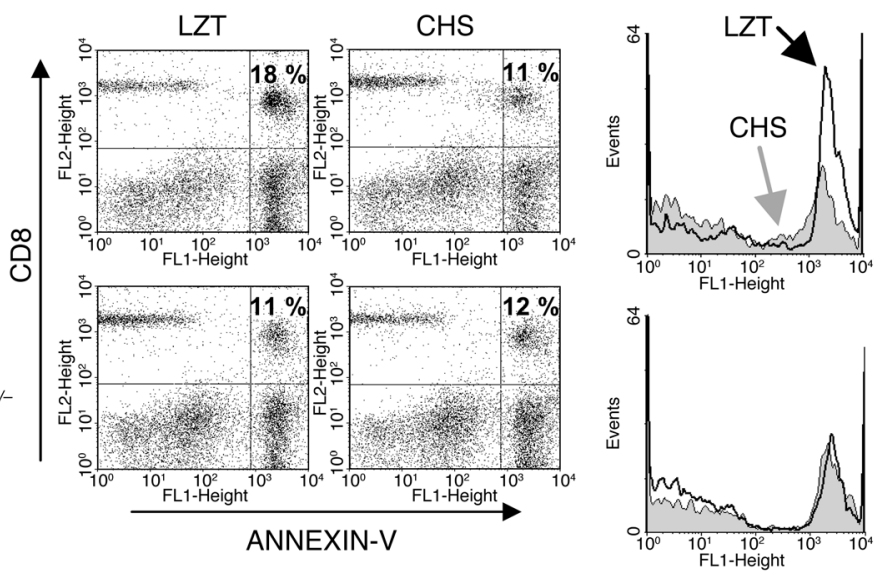

B

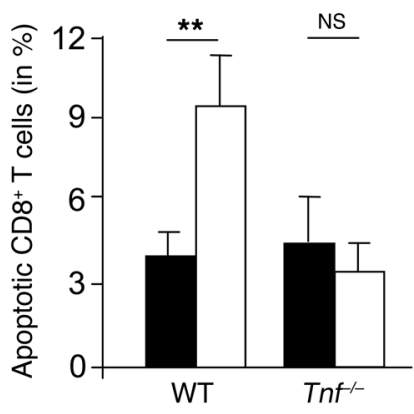

$\square$ Tolerized (4.5 $\mu \mathrm{g}$ TNCB) $\rightarrow$ CHS

- Mock-tolerized (solvent) $\rightarrow$ CHS

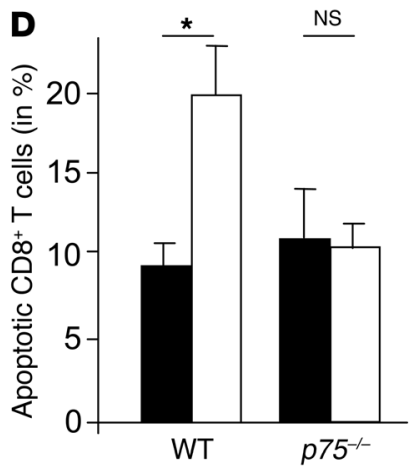

$\square$ Tolerized (4.5 $\mu$ g TNCB) $\rightarrow$ CHS

- Mock-tolerized (solvent) $\rightarrow$ CHS

E

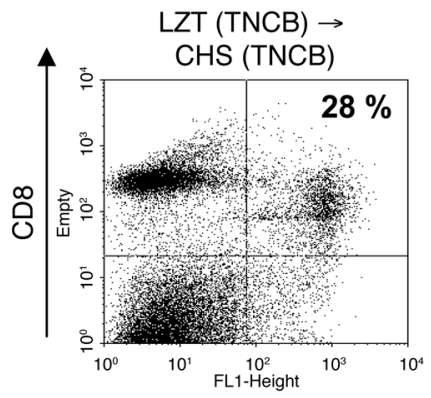

$\mathbf{F}$

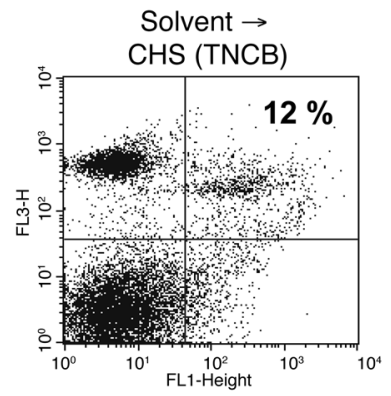

LZT (TNCB) $\rightarrow$

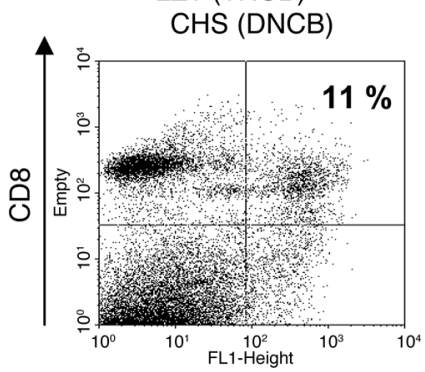

Solvent $\rightarrow$ $\mathrm{CHS}$ (DNFB)

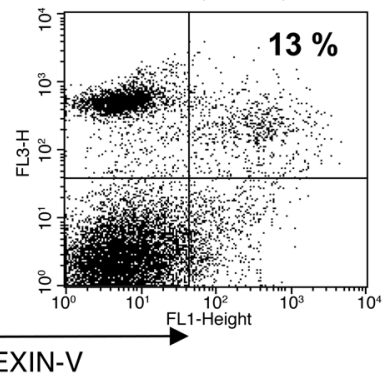

Tolerance induction TNCB

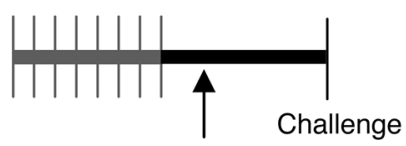

Sensitized TNCB
$\mathrm{CD}^{+} \mathrm{T}$ cells

TNCB

Tolerance induction

TNCB

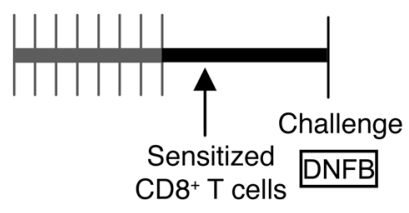

DNFB 


\section{Figure 6}

LZT is associated with increased TNF/p75-induced apoptosis in CHS effector CD8 ${ }^{+}$T cells. (A-D) Apoptosis in lymph node cells obtained 24 hours after challenge from tolerized and sensitized $\mathrm{Tnf}^{--}$and corresponding WT mice (A and B) and from $p 75^{-/-}$and corresponding WT mice (C and D). CD8 ${ }^{+} T$ cell apoptosis was detected by flow cytometry (annexin V staining, pooled cells obtained from 5-6 animals). 1 of 4 experiments with similar results $(\mathbf{A}$ and $\mathbf{C})$ and pooled data of 4 experiments $(\mathbf{B}$ and $\mathbf{D})$ are shown. (E and $\mathbf{F})$ Percentages of apoptotic Thy $1.2^{+} \mathbf{C D} 8^{+} \mathbf{T}$ cells as assessed by flow cytometry (annexin $\mathrm{V}^{+} / \mathrm{CD}^{+}$) in lymph node cells obtained after challenge with TNCB from TNCB-tolerized or mock-tolerized Thy $1.1^{+}$mice that were then reconstituted with T cells isolated from TNCB-sensitized Thy $1.2+$ mice (E) or in lymph node cells obtained after challenge with DNFB from TNCB-tolerized or mock-tolerized Thy1.1+ mice that had been reconstituted with T cells isolated from DNFB-sensitized Thy $1.2^{+}$mice (F). For analyses, gate was set on Thy $1.2^{+} \mathrm{T}$ cells (derived from the sensitized donor mice). 1 of 3 independent experiments with similar results is shown. 5 per group per experiment were used. Data are shown as mean $\pm \mathrm{SD}$. ${ }^{*} P<0.05 ;{ }^{* *} P<0.01$.

the induction phase and a diminished recruitment of inflammatory immune cells to the skin during the elicitation phase $(13,44-47)$. Our data suggest that in allergen-specific immune responses, TNF may act both as an activator (resulting in CHS) and a suppressor of the immune system (resulting in tolerance to allergens), depending on the form of TNF involved (transmembrane vs. soluble), the receptor (p55 vs. p75) engaged, and the immune cell population targeted.
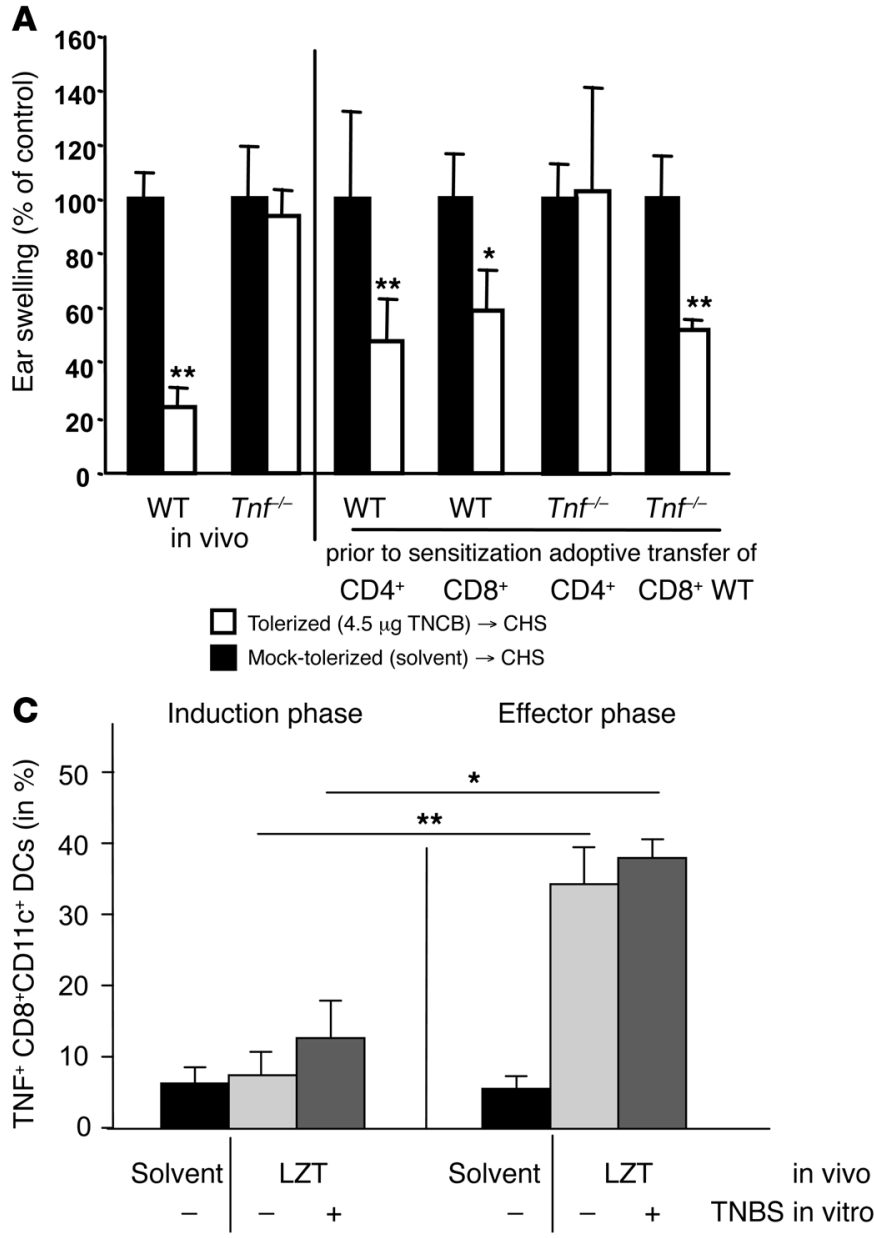

B

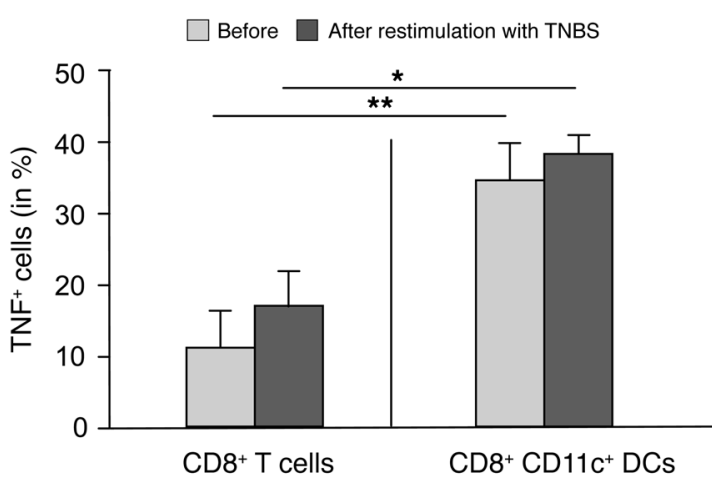

CD8 ${ }^{+} \mathrm{T}$ cells
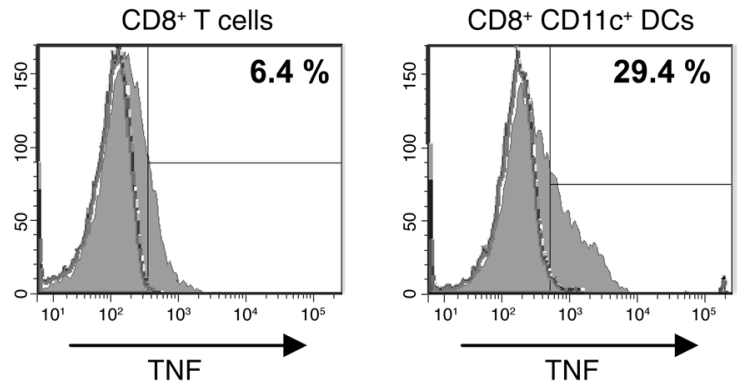

Figure 7

CD8+ DCs are the critical source for TNF in LZT. (A) LZT assessed by measuring CHS responses after challenge in tolerized (white bars) or mock-tolerized (solvent-treated; black bars) WT mice and $\mathrm{Tnf}^{-1}$ mice that were then sensitized, and in tolerized or solvent-treated WT mice or $\mathrm{Tnf}^{-1}$ mice that were first injected with $\mathrm{CD} 4^{+}$or $\mathrm{CD} 8^{+}$lymph node cells from naive WT mice and then sensitized. 1 of 3 independent experiments with similar results is shown (5-6 mice per group and per experiment). (B) Percentage of TNF-positive CD8 ${ }^{+} \mathrm{T}_{\text {cells and TNF-positive }}$ $\mathrm{CD}^{+}{ }^{+} \mathrm{CD} 11 \mathrm{c}+$ DCs obtained from tolerized, sensitized, and challenged WT mice as assessed by flow cytometry (staining for intracellular TNF) before and after restimulation with TNBS in vitro 24 hours after challenge (during the effector phase of LZT). Pooled data of 3 to 5 independent experiments with similar results ( 5 mice per group per experiment) (upper panel) and from 1 representative experiment (lower panels) are shown. (C) Percentage of TNF-positive CD8 ${ }^{+}$CD11 $\mathrm{c}^{+}$DCs obtained before challenge (during the LZT induction phase) or after challenge (during the LZT effector phase) from tolerized mice that had been sensitized and challenged or mock-tolerized (solvent-treated) animals. Cells were analyzed by intracellular FACS staining for TNF before or after restimulation with TNBS. Pooled data of 3 to 5 independent experiments with similar results (5 mice per group per experiment) are demonstrated. Data are shown as mean \pm SD. ${ }^{*} P<0.05 ;{ }^{* \star} P<0.01$. 
A

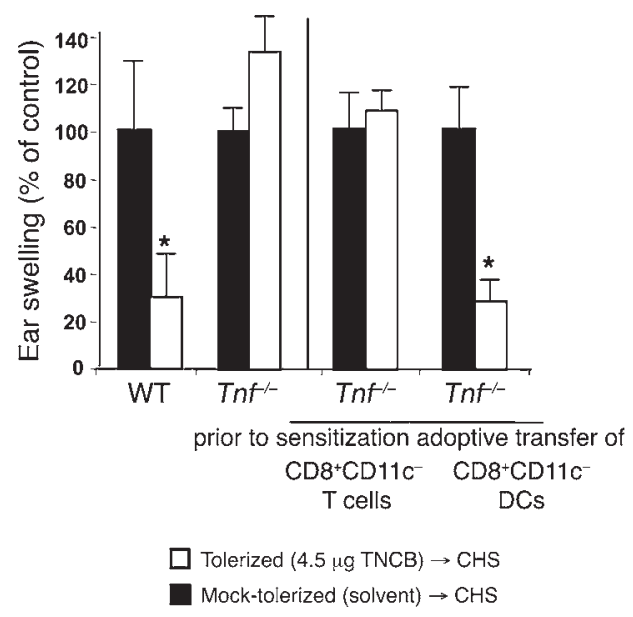

C

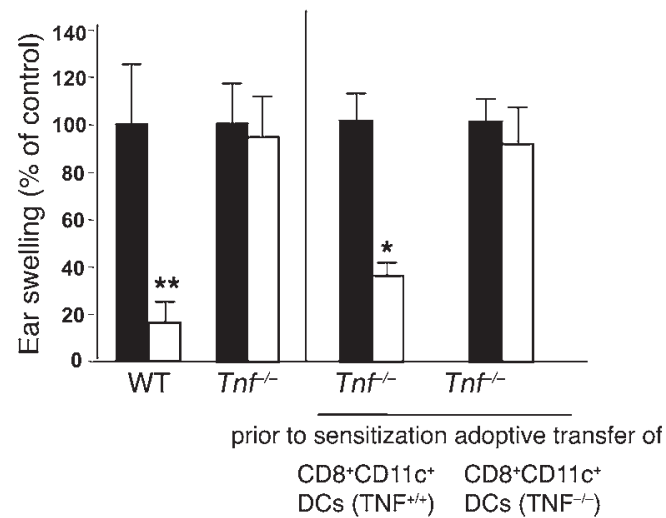

E

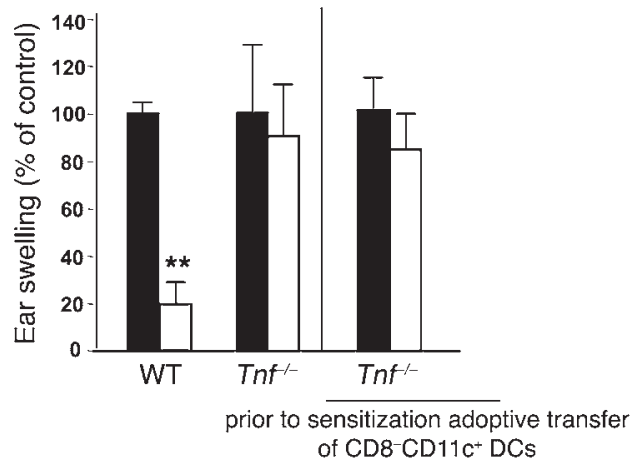

G

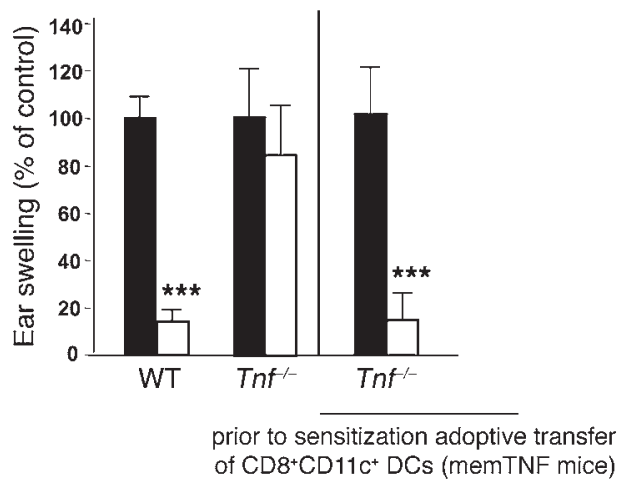

B

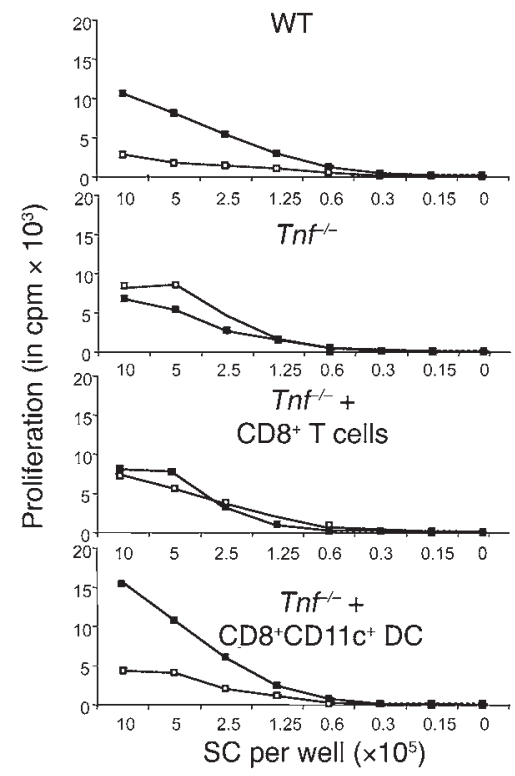

D

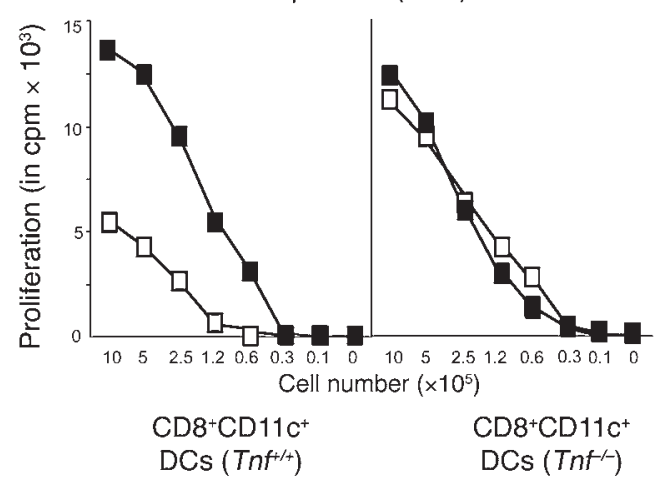

$\mathbf{F}$

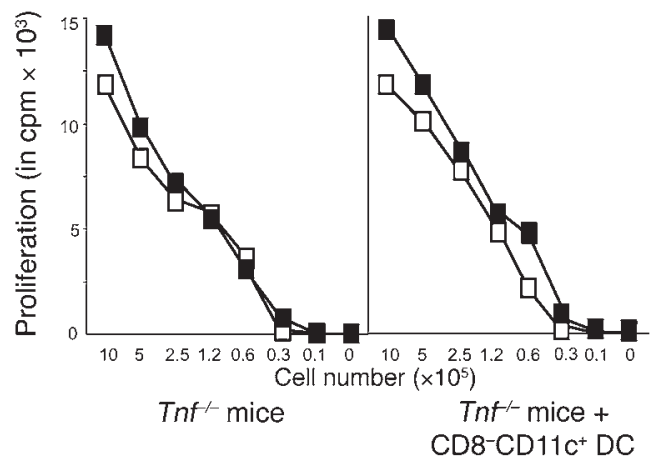

H

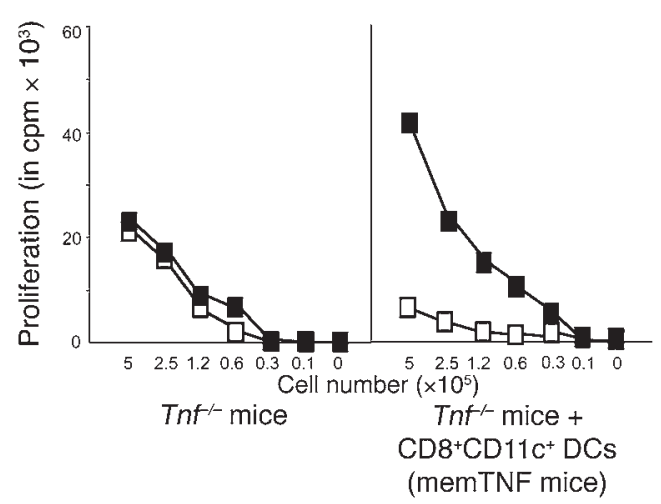




\section{Figure 8}

CD8 ${ }^{+}$CD $11 \mathrm{C}^{+}$DC-derived TNF is essential for LZT. LZT responses measured by assessing inhibition of CHS-associated ear swelling $(\mathbf{A}, \mathbf{C}, \mathbf{E}$, and $\mathbf{G})$ and $\mathbf{T}$ cell proliferation $(\mathbf{B}, \mathbf{D}, \mathbf{F}$, and $\mathbf{H})$ in tolerized and sensitized (white bars and white symbols) or mock-tolerized and sensitized (solvent-treated; black bars and symbols) WT mice and $\mathrm{Tnf}^{-1}$ mice, in $\mathrm{Tnf}^{-1}$ mice that were first adoptively transferred with highly purified $(>99.9 \%) \mathrm{CD}^{+} \mathrm{CD} 11 \mathrm{c}^{-} \mathrm{T}$ cells or $\mathrm{CD} 8{ }^{+} \mathrm{CD} 11 \mathrm{C}^{+}$ DCs isolated from naive WT mice and then sensitized (A and $\mathbf{B})$, in $\mathrm{Tnf}^{-1}$ mice that were first adoptively transferred with highly purified CD8 ${ }^{+}$CD $11 \mathrm{C}^{+}$DCs isolated from naive $\mathrm{Tnf}^{-1-}$ or WT mice and then sensitized (C and $\mathbf{D})$, in $\mathrm{Tnf}^{-/-}$mice that were first adoptively transferred with highly purified CD8-negative CD11 $\mathrm{C}^{+} \mathrm{DCs}$ isolated from naive WT animals and then sensitized (E and $\mathbf{F}$ ), or in $\mathrm{Tnf}^{-/-}$mice that were first adoptively transferred with highly purified $\mathrm{CD} 8^{+} \mathrm{CD} 11 \mathrm{C}^{+}$ DCs isolated from naive memTnf ${ }^{-1}$ mice and then sensitized ( $G$ and H). 1 of 2 independent experiments with similar results is shown (5-6 mice per group and per experiment). Data are shown as mean \pm SD. ${ }^{\star} P<0.05 ;{ }^{* *} P<0.01 ;{ }^{* \star} P<0.001$.

DCs comprise multiple subsets and exhibit crucial functions as activators and regulators of immune processes including tolerance induction $(48,49)$. Although the underlying mechanisms have not been fully elucidated, it is widely held that DCs exert their tolerogenic effects by suppressing $T$ cell responses, e.g., via the release of immunosuppressive mediators and/or the expression of coinhibitory molecules that induce anergy or the development of regulatory $T$ cells $(48,49)$. Recently, some murine and human DC populations have been shown to have cytotoxic effects on tumor cells and $\mathrm{T}$ cells (50-53). As of yet, these killer DCs remain ill characterized in terms of the molecular mechanism of their cytotoxic effects; moreover, they share some properties of NK cells (52). Target cell killing by TNF/p75-dependent induction of apoptosis may be a killer DC mechanism not exclusive to LZT.

Recent studies have demonstrated that NK cells can contribute importantly to adaptive immunity including CHS $(23,24,54)$. In LZT, NK cells are dispensable for tolerance development.

Our study shows, for what we believe is the first time, that TNF-mediated T cell killing by tolerogenic DCs is required and sufficient for the suppression of allergic inflammation by LZT. $\mathrm{CD}^{+} \mathrm{CD} 11 \mathrm{c}^{+}$DCs generated in vivo by uptake of low doses of allergens and by activation of regulatory $\mathrm{T}$ cells are critical for $\mathrm{CHS}$ effector $\mathrm{CD}^{+} \mathrm{T}$ cell apoptosis, thereby preventing the development of allergic skin inflammation. Such killer DCs, which deliver signals of death rather than of activation or modulation to T cells, may be exploited therapeutically for depleting antigen-specific $\mathrm{T}$ cells and, thereby preventing allergic immune responses. Efforts to generate tolerogenic DCs in the laboratory have already met with some success $(48,49,55,56)$. Now that we have identified the killing protocol of tolerogenic DCs, we can develop novel and more effective forms of tolerance-enhancing therapies that are designed to reduce the frequency of antigen-specific pathogenic T cells and provide disease control in allergies or autoimmunity.

\section{Methods}

Mice. Tnf ${ }^{\prime-}$, TNF double receptor-deficient $\left(p 55^{-/} p 75^{-/-}\right)$, TNFR1-deficient $\left(p 55^{-/-}\right)$, TNFR2-deficient $\left(p 75^{--}\right)$, Rag1 $1^{-/-}$, CD 45.1, Thy 1.1 , and C57BL/6 WT littermate control mice originally purchased from Charles River and transgenic memTNF (provided by B. Ryffel, INSERM, Orléans, France) (all mice on C57BL/ 6 background) were bred in the animal facility of the Department of Dermatology of the University Medical Center of Mainz.
Mice were used between 8 and 12 weeks of age. All animal studies were approved by the Animal Care Committee of Rhineland-Palatinate and performed in accordance with current federal and institutional guidelines (University Medical Center Mainz).

Reagents and antibodies. Picryl chloride (TNCB; 2,4,6-trinitro-1-chlorobenzene; VeZerf Laborsynthesen), picryl sulfonic acid (TNBS; 2,4,6-trinitro-benzenesulfonic acid), and DNFB (1-fluoro-2,4-dinitrobenzene) (both Sigma-Aldrich) were used. Antibodies against CD4 (L3T4), CD8 (Ly-2), and Thy1.2 (53-2.1) used were purchased from BD Pharmingen; CD80, CD86, MHC class II, CD273, CD274, CD275, CD276, TNFR2, GITR, B7H4, CD95, CD103, and IgG2a (eBR2s) were purchased from eBioscience.

Tolerance induction. Experimental groups of knockout and WT mice were painted 10 times every other day with tolerizing doses of 0.45 or $4.5 \mu \mathrm{g}$ TNCB or in some experiments with $0.01 \%$ DNFB dissolved in $15 \mu$ l acetone/olive oil (AOO;v/v 3:1) or AOO alone as a control onto shaved areas of the body (see Supplemental Figure 1A). At day 20, mice were sensitized by epicutaneous application of $450 \mu \mathrm{g}$ TNCB or 1\% DNFB in $15 \mu \mathrm{l} \mathrm{AOO}$ (Supplemental Figure 1A). Challenge was performed by painting $45 \mu \mathrm{g}$ TNCB or $0.1 \%$ DNFB onto the dorsal side of the right ear at day 25 , and increase of ear thickness was measured after 24 hours using an engineers' micrometer (Oditest) (Supplemental Figure 1A). 5-7 mice per group were included. Results are expressed as mean values in units of $\mathrm{mm} \times 10^{-2}$ or percentage of control $\pm \mathrm{SD}$.

Preparation of lymph node cells, enriched T cells, and DCs for cell culture and adoptive transfer. Auricular, cervical, and inguinal lymph nodes were taken
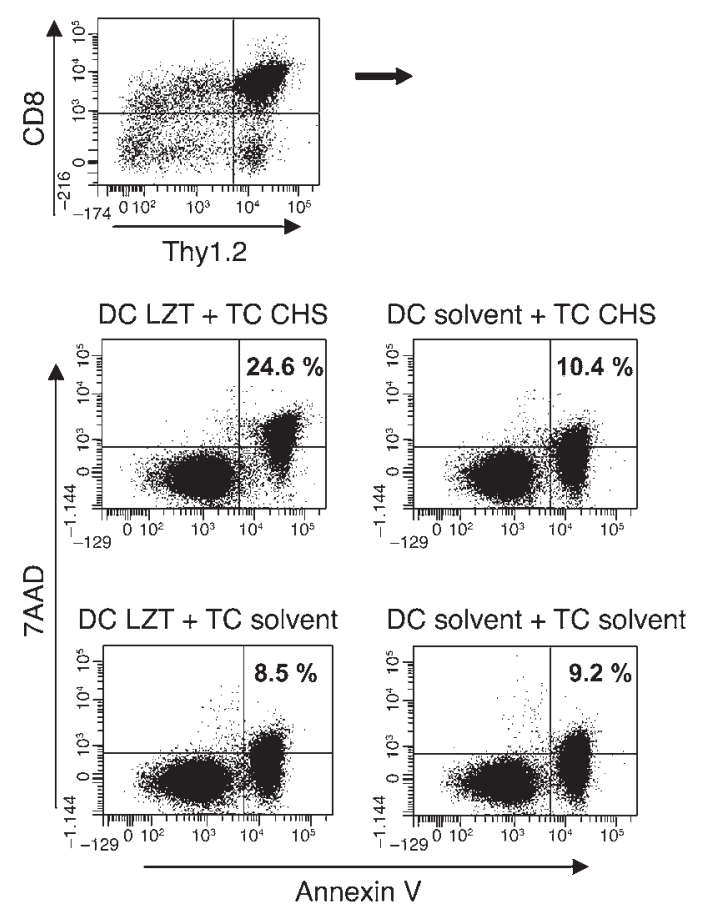

\section{Figure 9}

CD8 ${ }^{+} \mathrm{CD} 11 \mathrm{C}^{+} \mathrm{DC}$ induce apoptosis in $\mathrm{CD} 8^{+} \mathrm{CHS}$ effector $\mathrm{T}$ cells. Percentage of apoptosis (annexin $\mathrm{V}^{+} / 7-\mathrm{AAD}^{+}$) in $\mathrm{CD} 8^{+} \mathrm{CHS}$ effector $\mathrm{T}$ cells (TC CHS, obtained from sensitized and challenged Thy $1.2^{+}$mice, middle panel) and $\mathrm{CD}^{+} \mathrm{T}$ cells from mock-sensitized and -challenged Thy $1.2^{+}$mice (TC control, lower panel) cocultured at a ratio of 10:1 with CD8 ${ }^{+}$CD $11 c^{+}$DCs obtained from tolerized Thy $1.1^{+}$mice (DC LZT) or mock-tolerized (solvent-treated) Thy1.1+ mice (DC control). Gate was set on CD8+Thy1.2+ T cells (upper panel). Representative results from 3 independent experiments with 3 mice (for T cell isolation) and 12 mice (for DC isolation) per group and per experiment are shown. 
24 hours after challenge, 48 hours after the application of the last tolerization or of untreated animals, and passed through a sterile 70- $\mu \mathrm{m}$ nylon cell strainer. For cell culture, lymph node cells were resuspended in RPMI 1640 Complete (BioWhittaker) supplemented with $2 \%$ heat-inactivated syngeneic normal mouse serum at a concentration of $10^{6}$ cells $/ 200 \mu \mathrm{l}$. T cells and DCs were purified (T cells > 95\% purity, DCs > 85\% purity, viability 85\%-95\%, using anti-Thy-1.2- [CD90.2], anti-Thy-1.1- [CD90.1], antiCD5-, anti-CD8-, anti-CD4-, and CD11c-coated MACS beads [MACS system; Miltenyi Biotec $\mathrm{GmbH}]$ ). For isolation of $\mathrm{CD} 11^{+} \mathrm{DCs}$ or $\mathrm{CD} 11 \mathrm{c}^{+} \mathrm{CD} 8^{+}$ DCs, lymph nodes were incubated with collagenase type IV and DNase I (both CellSystems) prior to DC purification with MACS beads. T cells or $\mathrm{CD}^{+} / \mathrm{CD}^{+} \mathrm{T}$ cell populations were finally resuspended in RPMI 1640 Complete $\left(1 \times 10^{5}\right.$ cells $\left./ 100 \mu \mathrm{l}\right)$ and stimulated with $1 \times 10^{6}($ in $100 \mu \mathrm{l})$ haptenized and irradiated (30 Gy) spleen cells (SCs) (highest T cells [TC]: SC ratio: 1:10); titration experiments (1:2) of the SCs were performed.

Haptenization oflymphnodecells and SCs. Lymph node cells or SCs $\left(10^{7}\right.$ cells $\left./ \mathrm{ml}\right)$ were incubated in $10 \mathrm{mM}$ TNBS in HBSS for 10 minutes at $37^{\circ} \mathrm{C}$, subsequently washed 3 times in RPMI 1640 Complete, and resuspended in medium supplemented with $2 \%$ syngeneic normal mouse serum.

Proliferation assay. After 24 hours of culture, cells were pulsed with $1 \mu \mathrm{Ci}$ $\left[{ }^{3} \mathrm{H}\right]$ thymidine (Amersham Biosciences) for 18 hours. Incorporated radioactivity was determined using a liquid scintillation counter (1205 Betaplate; LKB Wallac). Results are expressed as mean cpm of triplicate wells \pm SD.

Adoptive transfer of T cells, $C D 8^{+} T$ cells, and $C D 4^{+} T$ cells. Tnf ${ }^{\prime-}, p 75^{-1-}$, or WT donor mice were treated with $4.5 \mu \mathrm{g}$ TNCB or AOO alone. After application of the last tolerizing dose or AOO, animals were killed and lymph nodes were taken. Enriched T cells, CD4 ${ }^{+} \mathrm{T}$ cells, and $\mathrm{CD}^{+} \mathrm{T}$ cells were prepared as described and injected i.v. into untreated WT, Tnf/-, or $p 75^{-/-}$recipients (one single injection of $2-3 \times 10^{7}$ cells $/ 100 \mu \mathrm{lBS}$ ). Subsequently, sensitization and challenge were performed as described above. In some experiments, tolerized WT and $p 75^{-1-}$ mice were injected with $\mathrm{CD}^{+}$and $\mathrm{CD}^{+} \mathrm{T}$ cells obtained from sensitized WT animals that were challenged 24 hours later.

Reconstitution of Tnf/- mice with WT CD $8^{+} C D 11 c^{+} D C$ s or $C D 8^{+} C D 11 c^{-} T$ cells. The capacity of $\mathrm{CD} 11^{+} \mathrm{CD}^{+}$DCs to migrate to lymphatic tissues and several organs after i.v. transfer has been demonstrated in many studies (53). Tnf $^{\prime-}$ mice were painted 10 times with $4.5 \mu \mathrm{g}$ TNCB or AOO. Two days after the last application, $\mathrm{Tnf}^{/-}$mice were reconstituted with i.v. injection of $\mathrm{CD}^{+} \mathrm{CD} 11 \mathrm{c}^{-} \mathrm{T}$ cells $\left(\right.$ Thy $\left.1.2^{+}\right)\left(1.5-2 \times 10^{6}\right)$ or $\mathrm{CD}^{+} \mathrm{CD} 11^{+} \mathrm{DCs}\left(1.5-2 \times 10^{4}\right)$ obtained from naive WT or memTNF donors (by cell sorting using a FACS sorter, FACStage SE, BD Biosciences, purity of T cells > 99.9\%, viability $85 \%-95 \%$, and anti-CD8 $\mathrm{mAb}$, anti-CD11 c mAb, BD Biosciences, anti-Thy1.2 mAb, eBioscience). DCs were Thy1.2, NK1.1, and TCR negative (anti-NK1.1 mAb, eBioscience; anti-TCR- $\alpha \beta$ chain $\mathrm{mAb}$, Serotec), excluding contamination with T cells. Purified CD8-CD11 $\mathrm{c}^{+}$DCs served as controls. For isolation of $\mathrm{CD} 11 \mathrm{c}^{+} \mathrm{CD} 8^{+} \mathrm{DCs}$, lymph nodes were incubated with collagenase type IV and DNase I (both from CellSystems) prior to DC purification with MACS beads. Subsequently, reconstituted or control $\operatorname{Tnf} /{ }^{-}$mice were sensitized and the challenge reaction was performed according to our standard protocol.

Neutralization of TNF by anti-TNF $m A$ b in vivo. Mice were i.p. treated with a rat anti-mouse TNF mAb (IgG2a, clone V1q, $100 \mu \mathrm{g} / 200 \mu \mathrm{l}$, provided by B. Echtenacher, University of Regensburg, Regensburg, Germany) every third day during the phase of tolerization or during tolerization, sensitization, and challenge. The ability of this antibody to inhibit murine TNF-mediated biologic activity and persistence in mice was described previously (44). To avoid problems due to anti-rat antibody production, tolerance induction was performed twice per day for 3 days, followed by sensitization and challenge.

NK depletion in vivo. WT were treated i.v. with antibodies to asialo-GM1 or rabbit IgG ( $25 \mu \mathrm{l}$ at days -1 and 3 ; both from WAKO Pure Chemical Industries) or injected i.p. with anti-NK1.1 mAb or IgG2a isotype control $(25 \mu \mathrm{g}$ per mice at day -1 ; both from eBioscience) during tolerization, or with a single application 24 hours before allergen challenge as described (23). NK cell depletion and recovery were controlled by flow cytometry in SCs and lymph node cells. After depletion during tolerance induction, sensitization and challenge were performed after repopulation of NK cells to avoid an effect on CHS induction.

Cytokine ELISAs. Cytokine ELISAs for TNF, IL-2, IFN- $\gamma$, and IL-10 were performed according to the manufacturer's instructions (IFN- $\gamma$ from R\&D systems; all others from BD Biosciences - Pharmingen) using culture supernatants.

Intracellular TNF staining. Intracellular cytokine staining of lymph node cells and DCs was performed using the Cytofix/CytoPerm Plus Kit (BD Biosciences) according to the manufacturer's instructions. Antibodies for detection of TNF (BD Biosciences) were used. CD8 ${ }^{+}$lymph node cells, CD8 ${ }^{+}$Thy $1.2^{+} \mathrm{T}$ cells, and $\mathrm{CD}^{+} \mathrm{CD} 11 \mathrm{c}^{+}$Thy $1.2^{-} \mathrm{DCs}$ were analyzed for intracellular TNF expression 2 days after the last application of a tolerizing dose (induction phase of LZT) and 24 hours after challenge (effector phase of LZT) and analyzed ex vivo and 24 hours after hapten-specific restimulation for cytokine expression.

For in vitro experiments, $\mathrm{CD}^{+} \mathrm{T}$ cells obtained from $\mathrm{LZT}$ or solventtreated control animals $\left(1 \times 10^{5}\right)$ were cocultured with $\mathrm{CD} 8^{+} \mathrm{CD} 11 \mathrm{c}^{+}$ DCs $\left(1 \times 10^{4}\right)$ purified from LZT or solvent-treated control mice or vice versa. Cells were haptenized or left untreated and analyzed by flow cytometry. Gate was set on $\mathrm{CD}^{+}$cells, and subsequently, percentage of $\mathrm{TNF}^{+} \mathrm{CD} 11 \mathrm{c}^{+} \mathrm{DCs}$ was analyzed.

In vivo migration of $C D 8^{+} C D 11 c^{+} D C s$. $C D 8^{+} \mathrm{CD} 11 \mathrm{c}^{+} \mathrm{DCs}$ were obtained from CD45.1 WT mice as described and injected into tolerized or solvent-treated control Tnf/- CD45.2 mice $\left(2 \times 10^{4} /\right.$ per mouse). Subsequently, recipients were sensitized. 24 hours after challenge, skin-draining lymph node cells were obtained and analyzed for CD $45.1 \mathrm{CD} 8{ }^{+} \mathrm{CD} 11 \mathrm{c}^{+} \mathrm{DCs}$ by flow cytometry.

ELISpot for IL-10 secretion. The ELISpot assay was performed according to the manufacturer's protocol (BD Biosciences - Pharmingen) and as described (5).

Detection of apoptotic T cells. Lymph node cells of WT, Tnf ${ }^{/-}$, and $p 75^{-/-}$ mice were obtained 24 hours after challenge. At 0 and 24 hours, cells were stained with anti-CD8 mAb and annexin V. Dead cells were excluded by propidium iodide (PI) staining, and $\mathrm{T}$ cells were gated prior to analyses. In adoptive transfer experiments, lymph node cells were analyzed using antiCD8 mAb (BD Biosciences), anti-Thy-1.2 mAb (eBioscience), anti-Thy-1.1 $\mathrm{mAb}$ (eBioscience), anti-p75 mAb (BD Biosciences), and annexin V-FITC staining. annexin $\mathrm{V}$ staining was performed using a detection kit (BD Biosciences) according to the manufacturer's protocol. Labeled cells were washed in calcium buffer and analyzed by flow cytometry (FACScan; BD). For analyses, gates were set on Thy $1.2^{+}$and/or Thy $1.1^{+}$cells, respectively, according to the experimental protocol.

For in vitro experiments, $\mathrm{CD}^{+} \mathrm{T}$ cells obtained from CHS or solventtreated control animals $\left(1 \times 10^{5}\right)$ were cocultured with $\mathrm{CD}^{+} \mathrm{CD} 11 \mathrm{c}^{+} \mathrm{DCs}$ $\left(1 \times 10^{4}\right)$ purified from LZT or solvent-treated mice or vice versa. Cells were haptenized or left untreated and analyzed by flow cytometry. Gate was set on $\mathrm{CD}^{+} \mathrm{T}$ cells, and subsequently, expression of annexin $\mathrm{V}$ and 7-AAD (eBioscience) was investigated.

Statistics. Statistical significances of differences between experimental groups were evaluated using the Wilcoxon-Mann-Whitney 2-sample test. Data are shown as mean \pm SD. $P<0.05$ was considered significant.

\section{Acknowledgments}

This study was supported in part by grants of the German Research Council (DFG) (STE 791/4-5, STE 791/5-1, TR52/A7 to K. Steinbrink; MA1909/6-1 to M. Maurer; and SFB650/TP21 to M. Maurer and M. Metz), grants from the Foundation of Rhineland-Palatinate (to K. Steinbrink), and intramural grants from the University of Mainz (to K. Steinbrink). We thank E. von Stebut-Borschitz, 
K. Mahnke, and E. Schmitt for helpful discussions, and J. Urcioli for proofreading of the manuscript.

Received for publication November 30, 2010, and accepted in revised form July 6, 2011.

1. Cavani A, De Pita O, Girolomoni G. New aspects of the molecular basis of contact allergy. Curr Opin Allergy Clin Immunol. 2007;7(5):404-408.

2. Steinbrink K, Sorg C, Macher E. Low zone tolerance to contact allergens in mice: a functional role for CD8+ T helper type 2 cells. J Exp Med. 1996; 183(3):759-768.

3. Steinbrink K, Kolde G, Sorg C, Macher E. Induction of low zone tolerance to contact allergens in mice does not require functional Langerhans cells. J Invest Dermatol. 1996;107(2):243-247.

4. Seidel-Guyenot W, Alt R, Perschon S, Knop J Steinbrink K. B cells are not required for $\mathrm{T}$ cell priming in low zone tolerance to contact allergens and contact hypersensitivity. Eur J Immunol. 2004;34(11):3082-3090.

5. Maurer M, Seidel-Guyenot W, Metz M, Knop J, Steinbrink K. Critical role of IL-10 in the induction of low zone tolerance to contact allergens. J Clin Invest. 2003;112(3):432-439.

6. Seidel-Guyenot W, Perschon S, Dechant N, Alt R, Knop J, Steinbrink K. Low zone tolerance induced by systemic application of allergens inhibits Tc1mediated skin inflammation. J Allergy Clin Immunol. 2006;117(5):1170-1177.

7. Locksley RM, Killeen N, Lenardo MJ. The TNF and TNF receptor superfamilies: integrating mammalian biology. Cell. 2001;104(4):487-501.

8. Carpentier I, Coornaert B, Beyaert R. Function and regulation of tumor necrosis factor type 2. Curr Med Chem. 2004;11(16):2205-2212.

9. Muppidi JR, Tschopp J, Siegel RM. Life and death decisions: secondary complexes and lipid rafts in TNF receptor family signal transduction. Immunity. 2004;21(4):461-465.

10. Apostolaki M, Armaka M, Victoratos P, Kollias G. Cellular mechanisms of TNF function in models of inflammation and autoimmunity. Curr Dir Autoimmun. 2010;11:1-26.

11. Xu H, DiIulio NA, Fairchild RL. T cell populations primed by hapten sensitization in contact sensitivity are distinguished by polarized patterns of cytokine production: interferon gamma-producing (Tc1) effector CD8+ T cells and interleukin (II) 4/IL-10-producing (Th2) negative regulatory CD4+ T cells. J Exp Med. 1996;183(3):1001-1012.

12. Wu AJ, Hua H, Munson SH, McDevitt HO. Tumor necrosis factor-alpha regulation of CD $4+\mathrm{CD} 25+\mathrm{T}$ cell levels in NOD mice. Proc Natl Acad Sci U S A. 2002;99(19):12287-12292.

13. Pasparakis M, Alexopoulou L, Episkopou V, Kollias G. Immune and inflammatory responses in TNF alpha-deficient mice: a critical requirement for TNF alpha in the formation of primary B cell follicles, follicular dendritic cell networks and germinal centers, and in the maturation of the humoral immune response. J Exp Med. 1996;184(4):1397-1411.

14. Tumanov AV, et al. Cellular source and molecular form of TNF specify its distinct functions in organization of secondary lymphoid organs. Blood. 2010;116(18):3456-3464

15. Grell M, et al. The transmembrane form of tumor necrosis factor is the prime activating ligand of the $80 \mathrm{kDa}$ tumor necrosis factor receptor. Cell. 1995;83(5):793-802.

16. Bazzoni F, Beutler B. The tumor necrosis factor ligand and receptor families. $N$ Engl J Med. 1996;334(26):1717-1725.

17. Black RA, et al. A metalloproteinase disintegrin that releases tumour-necrosis factor-alpha from
Address correspondence to: Kerstin Steinbrink, Department of Dermatology, University Medical Center, Johannes Gutenberg University Mainz, Langenbeckstrasse 1, 55131 Mainz, Germany. Phone: 49.6131.17.3792; Fax: 49.6131.17.5527; E-mail: kerstin. steinbrink@unimedizin-mainz.de. cells. Nature. 1997;385(6618):729-733

18. Pimentel-Muinos FX, Seed B. Regulated commitment of TNF receptor signaling: a molecular switch for death or activation. Immunity. 1999;11(6):783-793.

19. Ruuls SR, et al. Membrane-bound TNF supports secondary lymphoid organ structure but is subservient to secreted TNF in driving autoimmune inflammation. Immunity. 2001;15(4):533-543.

20. Zheng L, Fisher G, Miller RE, Peschon J, Lynch DH, Lenardo MJ. Induction of apoptosis in mature T cells by tumour necrosis factor. Nature. 1995; 377(6547):348-351.

21. Declercq W, Denecker G, Fiers W, Vandenabeele P. Cooperation of both TNF receptors in inducing apoptosis: involvement of the TNF receptor-associated factor binding domain of the TNF receptor 75 . J Immunol. 1998;161(1):390-399.

22. Teh HS, Seebaran A, Teh SJ. TNF receptor 2-deficient CD8 T cells are resistant to Fas/Fas ligand-induced cell death. J Immunol. 2000;165(9):4814-4821.

23. O'Leary JG, Goodarzi M, Drayton DL, von Andrian UH. T cell- and B cell-independent adaptive immunity mediated by natural killer cells. Nat Immunol. 2006;7(5):507-516.

24. Paust $\mathrm{S}$, et al. Critical role for the chemokine receptor CXCR6 in NK cell-mediated antigen-specific memory of haptens and viruses. Nat Immunol. 2010;11(12):1127-1135

25. Grivennikov SI, et al. Distinct and nonredundant in vivo functions of TNF produced by $t$ cells and macrophages/neutrophils: protective and deleterious effects. Immunity. 2005;22(1):93-104.

26. Gupta S, Gollapudi S. TNF-alpha-induced apoptosis in human naive and memory CD8+ T cells in aged humans. Exp Gerontol. 2006;41(1):69-77.

27. Vandenabeele P, Declercq W, Vanhaesebroeck B, Grooten J, Fiers W. Both TNF receptors are required for TNF-mediated induction of apoptosis in PC60 cells. J Immunol. 1995;154(6):2904-2913.

28. Hsu H, Shu HB, Pan MG, Goeddel DV. TRADDTRAF2 and TRADD-FADD interactions define two distinct TNF receptor 1 signal transduction pathways. Cell. 1996;84(2):299-308.

29. Weiss T, et al. Enhancement of TNF receptor p60-mediated cytotoxicity by TNF receptor p80: requirement of the TNF receptor-associated factor2 binding site. J Immunol. 1997;158(5):2398-2404.

30. Weiss T, et al. TNFR80-dependent enhancement of TNFR60-induced cell death is mediated by TNFRassociated factor 2 and is specific for TNFR60. J Immunol. 1998;161(6):3136-3142.

31. Chan FK, Lenardo MJ. A crucial role for p 80 TNF$\mathrm{R} 2$ in amplifying p60 TNF-R1 apoptosis signals in T lymphocytes. Eur I Immunol. 2000;30(2):652-660.

32. Fotin-Mleczek M, et al. Apoptotic crosstalk of TNF receptors: TNF-R2-induces depletion of TRAF2 and IAP proteins and accelerates TNF-R1dependent activation of caspase-8. J Cell Sci. 2002; 115(pt 13):2757-2770.

33. Faustman D, Davis M. TNF receptor 2 pathway: drug target for autoimmune diseases. Nat Rev Drug Discov. 2010;9(6):482-493.

34. Gupta S. A decision between life and death during TNF-alpha-induced signaling.J Clin Immunol. 2002;22(4):185-194.

35. Kim EY, Priatel JJ, Teh SJ, Teh HS. TNF receptor type 2 (p75) functions as a costimulator for antigen-driven T cell responses in vivo. J Immunol. 2006 ; 176(2):1026-1035.

36. Erickson SL, et al. Decreased sensitivity to tumour-necrosis factor but normal T-cell development in TNF receptor-2-deficient mice. Nature. 1994;372(6506):560-563.

37. van Mierlo GJ, et al. Cutting edge: TNFR-shedding by $\mathrm{CD} 4+\mathrm{CD} 25+$ regulatory $\mathrm{T}$ cells inhibits the induction of inflammatory mediators. J Immunol. 2008; 180(5):2747-2751.

38. Valencia X, Stephens G, Goldbach-Mansky R, Wilson M, Shevach EM, Lipsky PE. TNF downmodulates the function of human CD4+CD25hi T-regulatory cells. Blood. 2006;108(1):253-261.

39. Stoop JN, et al. Tumor necrosis factor alpha inhibits the suppressive effect of regulatory $\mathrm{T}$ cells on the hepatitis B virus-specific immune response. Hepatology. 2007;46(3):699-705.

40. Nadkarni S, Mauri C, Ehrenstein MR. Anti-TNFalpha therapy induces a distinct regulatory $\mathrm{T}$ cell population in patients with rheumatoid arthritis via TGF-beta. J Exp Med. 2007;204(1):33-39.

41. Chen X, Baumel M, Mannel DN, Howard OM, Oppenheim JJ. Interaction of TNF with TNF receptor type 2 promotes expansion and function of mouse CD4+CD25+ T regulatory cells. J Immunol. 2007;179(1):154-161.

42. Mercer F, Kozhaya L, Unutmaz D. Expression and function of TNF and IL-1 receptors on human regulatory T cells. PLoS One. 2010;5(1):e8639.

43. Enk AH, Katz SI. Early molecular events in the induction phase of contact sensitivity. Proc Natl Acad Sci U S A. 1992;89(4):1398-1402.

44. Wang B, et al. Depressed Langerhans cell migration and reduced contact hypersensitivity response in mice lacking TNF receptor p75. J Immunol. 1997; 159(12):6148-6155

45. Biedermann T, et al. Mast cells control neutrophil recruitment during $T$ cell-mediated delayed-type hypersensitivity reactions through TNF and MIP 2. J Exp Med. 2000;192(10):1441-1451.

46. Becke FM, Hehlgans T, Brockhoff G, Mannel DN. Development of allergic contact dermatitis requires activation of both tumor necrosis factor-receptors. Eur Cytokine Netw. 2001;12(1):45-50.

47. Suto H, Nakae S, Kakurai M, Sedgwick JD, Tsai M, Galli SJ. Mast cell-associated TNF promotes dendritic cell migration. J Immunol. 2006; 176(7):4102-4112.

48. Steinman RM, Hawiger D, Nussenzweig MC. Tolerogenic dendritic cells. Annu Rev Immunol. 2003;21:685-711.

49. Morelli AE, Thomson AW. Tolerogenic dendritic cells and the quest for transplant tolerance. Nat Rev Immunol. 2007;7(8):610-621.

50. Legge KL, Braciale TJ. Lymph node dendritic cells control CD8+ T cell responses through regulated FasL expression. Immunity. 2005;23(6):649-659.

51. Taieb J, et al. A novel dendritic cell subset involved in tumor immunosurveillance. Nat Med. 2006;12(2):214-219.

52. Spits H, Lanier LL. Natural killer or dendritic: what's in a name? Immunity. 2007;26(1):11-16.

53. Shortman K, Heath WR. The CD8+ dendritic cell subset. Immunol Rev. 2010;234(1):18-31.

54. Sun JC, Beilke JN, Lanier LL. Adaptive immune features of natural killer cells. Nature. 2009; 457(7229):557-561.

55. Steinman RM, Banchereau J. Taking dendritic cells into medicine. Nature. 2007;449(7161):419-426.

56. Palucka K, Banchereau J, Mellman I. Designing vaccines based on biology of human dendritic cell subsets. Immunity. 2010;33(4):464-478. 